\begin{tabular}{l} 
Sharif University of Technology \\
Scientia Iranica \\
SCIENTIA \\
IRAN \\
Thansactions A: Civil Engineering \\
\hline
\end{tabular}

\title{
Shear strength characteristics of a thermally cured sand-bentonite mixture
}

\author{
A. Hamidi ${ }^{a, *}$, A. Shirasb ${ }^{a}$, and M.M. Ahmadi ${ }^{b}$ \\ a. Department of Civil Engineering, School of Engineering, Kharazmi University, Tehran, Iran. \\ b. Department of Civil Engineering, Sharif University of Technology, Tehran, Iran.
}

Received 12 August 2020; received in revised form 7 March 2021; accepted 17 May 2021

\author{
KEYWORDS \\ Thermal curing; \\ Sand-bentonite \\ mixture; \\ Consolidated \\ undrained triaxial \\ tests; \\ Quasi-structured \\ behavior; \\ Temperature.
}

\begin{abstract}
An experimental program was employed to evaluate the effects of curing time and temperature on the shear behavior of a sand-bentonite mixture. The specimens were treated at temperatures of $40^{\circ} \mathrm{C}, 60^{\circ} \mathrm{C}$, and $80^{\circ} \mathrm{C}$ on Days 1,3 , and 5 under $100 \mathrm{kPa}$, $500 \mathrm{kPa}$, and $1000 \mathrm{kPa}$ confinements. The results of the consolidated undrained triaxial shear tests indicated that an increase in the temperature from $40^{\circ} \mathrm{C}$ to $80^{\circ} \mathrm{C}$ on Days 1 , 3 , and 5 of curing intensified the shear strength by $25 \%, 24 \%$, and $23 \%$, respectively. In addition, an increase in the curing time from 1 to 3 and from 1 to 5 days at $80^{\circ} \mathrm{C}$ increased the shear strength of samples up to $12 \%$ and $24 \%$, respectively. The failure of pre-cured samples was observed in lower strains as a result of greater induced brittleness. Moreover, the secant modulus and size of yield loci as well as slope of the critical state line increased by pre-curing. Application of thermal cycles resulted in increasing the shear strength and experiencing a negative pore water pressure that exhibited a transition towards the quasistructured behavior. The results of Scanning Electron Microscopy (SEM) studies confirmed an increase in the void ratio during thermal curing.
\end{abstract}

(C) 2021 Sharif University of Technology. All rights reserved.

\section{Introduction}

The thermo-mechanical behavior of clays has been widely studied by a number of researchers owing to their utilization of thermal technology such as energy piles, energy conservation, hazardous wastes disposal, and recovery systems in soils and rocks in many countries as well as the Aquifer Thermal Energy Storage (ATES) systems in Iran [1]. A number of experiments have been conducted on the behavior of clays in the

\footnotetext{
*. Corresponding author. Tel.: +982188830891 E-mail addresses: hamidi@khu.ac.ir (A. Hamidi); std_shirasb@khu.ac.ir (A. Shirasb); mmahmadi@sharif.edu (M.M. Ahmadi)
}

doi: $10.24200 /$ sci.2021.56550.4782 temperature range of $20^{\circ} \mathrm{C}$ to $100^{\circ} \mathrm{C}$ with respect to the significance of clay behavior at elevated temperatures. Based on the results of previous studies, both the temperature and time affect the behavior of clayey soils depending on soil type, mineralogy, and test conditions.

In many cases, clay or clay mixtures are exposed to elevated temperatures in a long period of time such as the buffer layer of high-level radioactive wastes, energy piles, and electricity buried cables, to name a few. This type of behavior has been investigated in a number of studies by applying a constant temperature for a specific time period. Long time temperature induces variations in diffuse double layers of clay and its mechanical properties such as compressibility, pore water pressures, strength, and hydraulic conductivity [2]. In many other studies, a quasi-structured type of behavior or a secondary structure has been 
reported for clays subjected to thermal loading for a period of time [3,4]. In this regard, Pusch and Guven conducted microscopic studies of [5] to evaluate the effects of temperature and confined pressure on the bentonite structure to demonstrate that the application of elevated temperatures for a long time could affect montmorillonite flakes to form a denser structure separated by larger voids. In addition, Scanning Electron Microscopy (SEM) studies performed by Attah and Etim [6] on clayey sand also revealed that the initial porous structure of soil turned to a dense fragmented one after preheating to $150^{\circ} \mathrm{C}$ for 4 hours. Shirasb et al. [7] evaluated the effect of thermal pre-curing on the consolidation characteristics of a sand-bentonite mixture and illustrated the transition of behavior from reconstituted to a structured one with a distinct yield stress. The yield stress increased upon increasing the curing time and temperature.

The temperature can effectively affect the soil behavior and its shear strength [8,9]. However, a brief review of previous studies reveals that despite several studies conducted on the thermal behavior of clays, the effects of applying long-time temperature have not been considered in studying the shear behavior of clay soils. In the present study, the effect of thermal pre-curing on the shear behavior of a sand-bentonite mixture is precisely studied. To this end, the process was employed to reflect the status of the buffer layer of nuclear waste repositories or energy piles exposed to temperature gradients for a specific time which can also be subjected to shear stresses. The curing process was performed at different temperatures for different time periods to evaluate their effects on the soil behavior. A comprehensive experimental program was planned using consolidated undrained triaxial tests. The results were then compared with the mechanical response of the samples at ambient temperature and changes in the soil response were evaluated. Moreover, through SEM, the changes in the structure of the soil under study were monitored under different curing conditions.

\section{Materials and properties}

A type of sodium bentonite with the Liquid Limit (LL) of $179 \%$ and Plasticity Index (PI) of $125 \%$ which is classified as $\mathrm{CH}$ according to USCS as well as fine and crushed well graded silica sand were used in this study. The LL and PI of the buffer layer in FEBEX site were about $102 \%$ and $49 \%$, respectively; however, these values were reported as $75 \%$ and $55 \%$ for Boom Clay in CERBERUS and ATLAS tests [10]. Figure 1 depicts the gradation curves, and Table 1 shows the physical properties of the used soils. Table 2 shows the chemical composition of sand and bentonite.

Various studies have reported different bentoniteto-sand weight ratios [11]. Based on oedometer tests

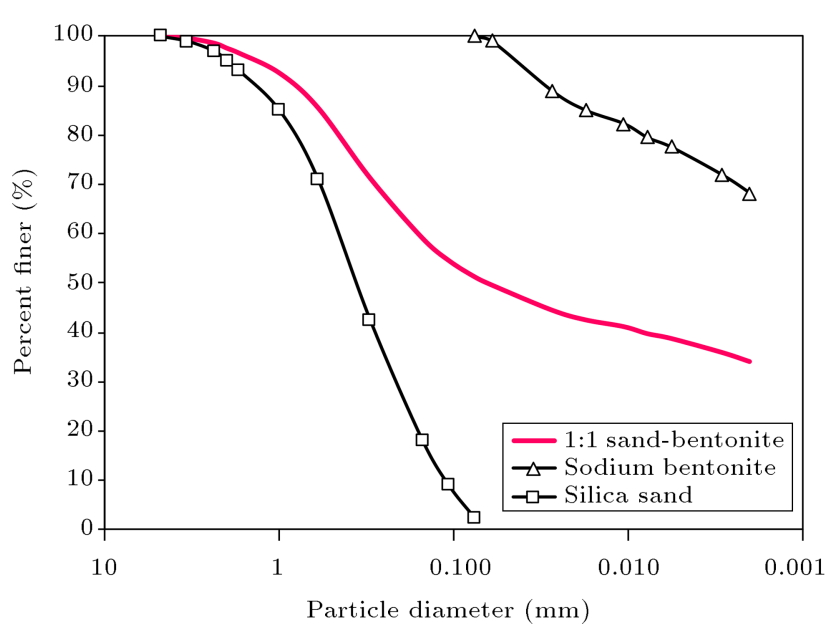

Figure 1. Particle size distribution curves of silica sand, sodium bentonite, and 1:1 sand-bentonite mixture.

Table 1. Physical properties of the used soils.

\begin{tabular}{lccc}
\hline \multicolumn{1}{c}{ Property } & Sand & Bentonite & $\begin{array}{c}\mathbf{1 : 1} \\
\text { mixt ure }\end{array}$ \\
\hline Name (USCS $\left.{ }^{*}\right)$ & $\mathrm{SW}$ & $\mathrm{CH}$ & $\mathrm{CH}$ \\
Clay $(\%)$ & 0 & 68 & 34 \\
Silt $(\%)$ & 2 & 31 & 16.5 \\
Sand $(0.06 \mathrm{~mm}-0.2 \mathrm{~mm})$ & 23 & 1 & 12 \\
Sand $(0.2 \mathrm{~mm}-1 \mathrm{~mm})$ & 55 & 0 & 27.5 \\
Sand $(>1 \mathrm{~mm})$ & 20 & 0 & 10 \\
LL $(\%)$ & - & 179 & 83 \\
PI $(\%)$ & $\mathrm{NP}$ & 125 & 57 \\
$w_{\text {opt }}(\%)$ & - & - & 21.4 \\
$\gamma_{\max }\left(\mathrm{kN} / \mathrm{m}^{3}\right)$ & - & - & 17.76 \\
$\gamma_{d, \max }\left(\mathrm{kN} / \mathrm{m}^{3}\right)$ & - & - & 17.0 \\
\hline
\end{tabular}

*USCS: Unified Soil Classification System.

Table 2. Chemical composition of soils.

\begin{tabular}{ccc} 
Chemical composition & Bentonite & Silica sand \\
\hline $\mathrm{SiO}_{2}$ & 58.12 & 96.0 \\
$\mathrm{Al}_{2} \mathrm{O}_{3}$ & 14.43 & 1.99 \\
$\mathrm{Fe}_{2} \mathrm{O}_{3}$ & 3.01 & 0.24 \\
$\mathrm{Na}_{2} \mathrm{O}$ & 3.01 & 0.07 \\
$\mathrm{MgO}$ & 2.79 & 0.43 \\
$\mathrm{CaO}$ & 2.13 & 0.64 \\
$\mathrm{~K}_{2} \mathrm{O}$ & 58.12 & 0.63 \\
$\mathrm{CL}$ & 1.47 & - \\
$\mathrm{SO}_{3}$ & 0.46 & - \\
$\mathrm{TiO}_{2}$ & 0.3 & - \\
$\mathrm{P}_{2} \mathrm{O}_{5}$ & 0.1 & - \\
$\mathrm{L}_{2} \mathrm{O} . \mathrm{I}$ & 13.07 & - \\
& &
\end{tabular}

on various sand-clay mixtures, it was concluded that the behavior of mixtures was significantly affected by the amount of clay and size or shape properties of 
sand grains [12]. In a study on gas migration through saturated bentonite-sand mixtures, Liu et al. [13] used a 3:7 weight ratio of sodium bentonite to silica sand to achieve the least permeability. The thermal conductivity of buffer is an important factor for HLW disposals depending on dry density, water content, and sand content [14].

Dixon et al. [15] defined effective porosity $\left(n_{e f f}\right)$ as another factor to calculate the optimum weight ratio of bentonite to sand in buffer layers based on Eq. (1):

$$
n_{e f f}=1-\rho_{d}\left(\frac{1}{G_{s, \text { mix }}}+\frac{0.15 F}{1+F}\right),
$$

where $\rho_{d}$ is the maximum dry density, $G_{s, \text { mix }}$ the specific gravity of mixture, and $F$ the weight ratio of clay to sand fractions. To obtain the most appropriate and impermeable protecting layer with minimum effective porosity, a 1:1 mixture by weight of silica sand and sodium bentonite was used [7]. The same ratio was selected in other programs on HLW disposals in Germany as well as Canada [16]. Drinkable water was used in sample preparation whose chemical composition is presented in Table 3 .

The stress-strain behavior of soils depends on their mineralogy, and the response of the samples with higher plasticity characteristics is significantly affected by temperature [17]. While investigating the plasticity changes in the studied soil during curing, some index tests were done on thermally-cured sandbentonite mixtures to determine variations in LL and PI. The results of index tests are shown in Figure 2. The values of LL and PI were $83 \%$ and $57 \%$, respectively, at ambient temperature. However, both LL and PI decreased at the curing temperatures of 20$80^{\circ} \mathrm{C}$, mainly due to the formation of larger particles

Table 3. Chemical analysis of the used water.

\begin{tabular}{cc}
\hline Parameter & Content \\
\hline $\mathrm{Cl}$ & $374 \mathrm{mg} / \mathrm{L}$ \\
$\mathrm{SO}_{4}$ & $320 \mathrm{mg} / \mathrm{L}$ \\
$\mathrm{Na}$ & $230 \mathrm{mg} / \mathrm{L}$ \\
$\mathrm{Ca}$ & $75.2 \mathrm{mg} / \mathrm{L}$ \\
$\mathrm{Mg}$ & $19.4 \mathrm{mg} / \mathrm{L}$ \\
$\mathrm{NO}_{3}$ & $38.0 \mathrm{mg} / \mathrm{L}$ \\
$\mathrm{K}$ & $1.2 \mathrm{mg} / \mathrm{L}$ \\
$\mathrm{NO}_{2}$ & $<0.1 \mathrm{mg} / \mathrm{L}$ \\
$\mathrm{PO}_{4}$ & $<0.1 \mathrm{mg} / \mathrm{L}$ \\
$\mathrm{F}$ & $<0.1 \mathrm{mg} / \mathrm{L}$ \\
$\mathrm{Br}_{\mathrm{Li}}$ & $<0.1 \mathrm{mg} / \mathrm{L}$ \\
$\mathrm{pH}\left(T=25^{\circ} \mathrm{C}\right)$ & $80.3 \mathrm{mg} / \mathrm{L}$ \\
$\mathrm{Conductivity}$ & $1655.3 \mu \mathrm{s} / \mathrm{cm}$ \\
\hline
\end{tabular}

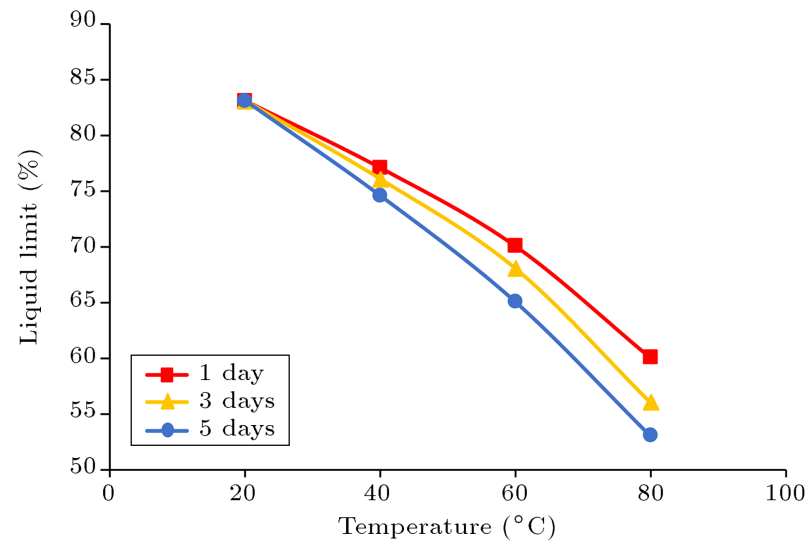

(a)

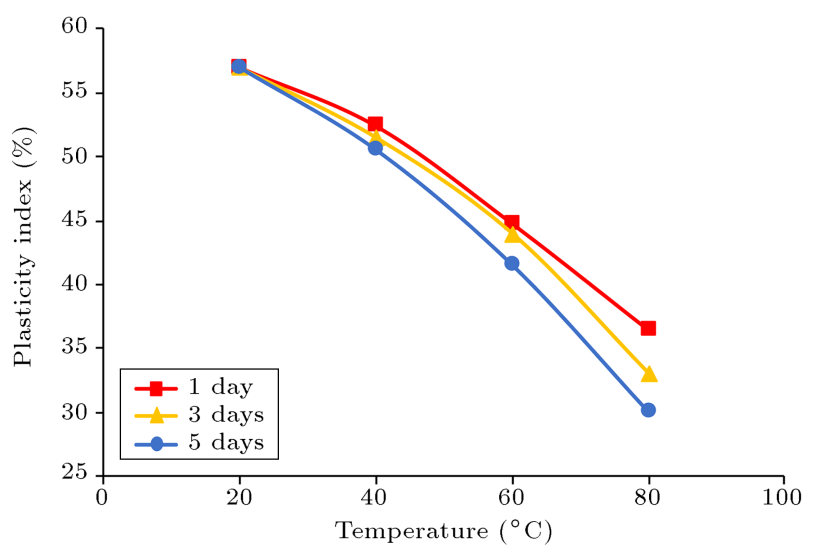

(b)

Figure 2. Variations of liquid limit and plasticity index with curing time and temperature.

resulting from water precipitation around clay particles and pasting clay [18]; in addition, reduction of specific surface caused by drying and the subsequent decrease in the water absorption capacity of clay particles were other reasons for such a decrease [19] in the range of the mentioned temperatures in the present study (up to $80^{\circ} \mathrm{C}$ ). At high temperatures, transformation from a mineral to another type causes changes in initial fabric [20-22]. The same trend for two different tropical clayey sands was observed by Attah and Etim [6].

The swelling pressure of the studied soil was determined based on the method C of ASTM D4546 [23]. It was regarded as the pressure at which the swelling of specimen was prevented. The swelling pressure was calculated as approximately $20 \mathrm{kPa}$ after four stages of increasing pressure. The obtained value is in agreement with the empirical equations of Erzin and Erol [24]. The low plasticity of the applied bentonite (PI $=57 \%$ ) caused swelling pressure to be much lower than the values reported by Komine and Nobuhide [25], i.e., about $100 \mathrm{kPa}$ for a mixed soil containing $30 \%$ bentonite with a PI of $447 \%$. It is expected to obtain lower swelling pressure after thermal curing due to a reduction in the plasticity characteristics. 


\section{Triaxial testing program}

Silica sand and bentonite were mixed and compacted in eight equal layers in a cylindrical mold of $100 \mathrm{~mm}$ in diameter and $200 \mathrm{~mm}$ in height. A compaction ratio of $90 \%$ was reached by adding de-aired water to achieve a dry unit weight of $15.3 \mathrm{kN} / \mathrm{m}^{3}$. An optimum water content of $21.4 \%$ and maximum dry density of $17 \mathrm{kN} / \mathrm{m}^{2}$ were also obtained for the sandbentonite mixture based on the modified Proctor test using a $4.5 \mathrm{~kg}$ weight hammer and a mold of $100 \mathrm{~mm}$ in diameter under 25 blows in each of five layers. The dry density of sand-bentonite mixture in the buffer layer of nuclear waste disposals was measured as 14.7 to $16.3 \mathrm{kN} / \mathrm{m}^{3}$ in a number of experiments in which the weight sand-bentonite mixture at 1:1 was used at the compaction ratio of $85 \%$ to $95 \%[15,26]$. In CERBERUS and ATLAS tests as well as the Boom Clay at Hades laboratory in Mol, a dry density of 15.8$17.5 \mathrm{kN} / \mathrm{m}^{3}$ was reported [10]. The bentonite used in FEBEX site had an average unit weight of 15.7-16.1 $\mathrm{kN} / \mathrm{m}^{3}$, as presented by ENRESA [27].

Consolidated undrained triaxial tests were carried out using a modified thermal triaxial cell with an electronic data logger system capable of measuring axial stress, axial strain, volume change, and excess pore water pressure, as illustrated in Figure 3 . The triaxial cell was calibrated to handle the pressures up to $2000 \mathrm{kPa}$ and temperatures up to $90^{\circ} \mathrm{C}$. Heating was induced by a spiral heater placed around the specimen controlled by a thermocouple placed vertically in the cell at a distance of $10 \mathrm{~mm}$ from the sample with a precision rate of $0.1^{\circ} \mathrm{C}$. Due to the small dimensions of specimens, the temperature at a center of the sample was equal to the cell temperature after 100 minutes which was measured in the calibration process.

After preparing the specimen, a back pressure of $700 \mathrm{kPa}$ was applied until achieving Skempton's $B$ value of 0.95 during six days of saturation. The final $B$ coefficient depends on several factors including clay content, plasticity characteristics, back pressure, and saturation time. With the consideration of the lower Liquid Limit $(L L=83 \%)$ and Plasticity Index $(P I=57 \%)$ of the mixture used in the present study, the applied back pressure and saturating time were consistent with the results from a study conducted by Mukherjee and Mishra [28] who obtained a $B$-value of 0.93 using back pressures of 480 to $565 \mathrm{kPa}$ in $12-17$ days for two sand-bentonite mixtures with $10 \%$ and $20 \%$ clay contents $(L L=286 \%$ ), respectively.

The curing temperatures were chosen so that they can fit with different thermal applications such as buffer layer in HLW disposal, energy piles, or underground buried power cables. The design temperature for the buffer layer of HLW disposals should not exceed $90^{\circ} \mathrm{C}$ due to the reduction of plasticity characteristics. In

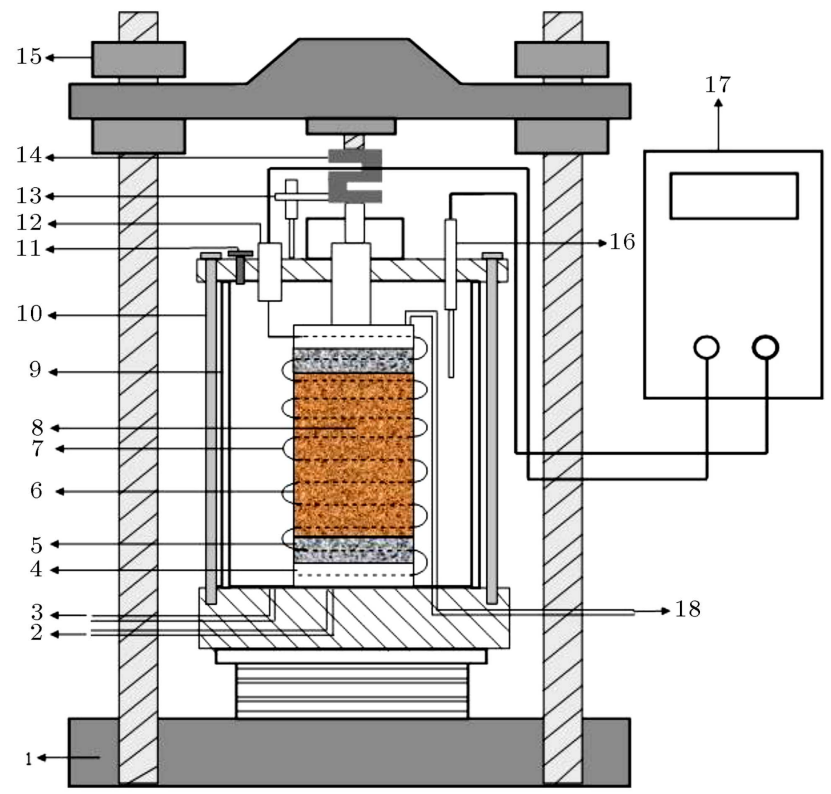

Figure 3. Schematic diagram of the pressure chamber in the temperature-controlled triaxial test system. (1) Loading frame, (2) Pore pressure line and testing tube, (3) Confining pressure line and testing tube, (4) Ceramic plate, (5) Porous stone, (6) Rubber membrane, (7) Heater, (8) Soil sample, (9) Stainless steel cylinder, (10) Fixed rods of pressure chamber, (11) Venture valve, (12) Heating source, (13) Axial displacement sensor, (14) Axial load piston and sensor, (15) Fixing bolt of loading frame, (16) Temperature sensor, (17) Temperature controller, and (18) Back pressure imposition and testing tube.

many cases, high temperature of HLW can be reduced before placing it in repositories [29]. The energy piles in Europe are designed for the temperature range of $-1^{\circ} \mathrm{C}$ to $35^{\circ} \mathrm{C}$. However, in some other cases, increasing temperature up to $40^{\circ} \mathrm{C}$ or $50^{\circ} \mathrm{C}$ is possible [30]. Maximum temperatures of $80^{\circ} \mathrm{C}$ and $60^{\circ} \mathrm{C}$ were reported around the buried cables and $0.25 \mathrm{~m}$ far from them, respectively [31].

The time required to finish the primary consolidation of the applied mixed soil was previously determined through isotropic consolidation tests by Shirasb et al. [7] whose findings revealed that the primary consolidation time increased upon increasing both temperature and confining pressure. The obtained values were less than $24 \mathrm{~h}$ at all temperatures under $100 \mathrm{kPa}$. When the confining pressure increased up to $500 \mathrm{kPa}$, it was achieved in less than $24 \mathrm{~h}$ at 20 , 40 , and $60^{\circ} \mathrm{C}$. At $1000 \mathrm{kPa}$, it was less than $24 \mathrm{~h}$ only at $20^{\circ} \mathrm{C}$ and $40^{\circ} \mathrm{C}$; however, it was less than $40 \mathrm{~h}$ at all temperatures and confinements [7]. For this reason, the pre-curing times of 1,3 , and 5 days were chosen in the present study.

Two sets of tests were carried out to study the shear behavior of sand-bentonite mixtures. In the first set, in order to evaluate the time-dependent thermal 
behavior of the mixed soil, the samples were pre-cured for one, three, and five days at constant temperatures of $40^{\circ} \mathrm{C}, 60^{\circ} \mathrm{C}$, or $80^{\circ} \mathrm{C}$ under the confining stresses of $100 \mathrm{kPa}, 500 \mathrm{kPa}$, or $1000 \mathrm{kPa}$ while keeping the drainage valve open. Similar to the findings of Lingnau et al. [26], the consolidation process was considered complete when the rate of volumetric strain was less than $0.1 \%$ day. The temperature was correctly controlled to remain constant during this time period and up to the end of the test. Moreover, three reference tests were done under the mentioned conditions and at ambient temperature of $20^{\circ} \mathrm{C}$. After consolidation, the undrained shear loading started at a rate of $0.2 \mathrm{~mm} / \mathrm{min}$. The loading continued up to the axial strain of about 20\%. During shear loading, deviatoric stress, axial strain, and excess pore water pressure were continuously measured using calibrated sensors and data acquisition system. To evaluate the effects of repeatability, $30 \%$ of the total triaxial tests were randomly repeated.

In the second group of tests, thermal stress paths were applied to the samples and their behavior was monitored. Two samples were heated from the ambient temperature $\left(20^{\circ} \mathrm{C}\right)$ to $80^{\circ} \mathrm{C}$ under the confining pressure of $100 \mathrm{kPa}$ for one and five days. Then, the temperature decreased again to the ambient value $\left(20^{\circ} \mathrm{C}-80^{\circ} \mathrm{C}-20^{\circ} \mathrm{C}\right)$ and sheared after thermal equilibrium in an undrained condition. The results were compared with those from the tests done on samples at the same curing time without any thermal cycling. Table 4 provides a summary of the testing program in this study.

\section{Results of triaxial tests}

\subsection{Stress-strain and pore pressure behavior}

Figures 4-6 show the deviatoric stress-axial strain and excess pore water pressure-axial strain curves of thermally cured samples obtained from consolidated undrained triaxial tests under initial confinements of 100, 500, and $1000 \mathrm{kPa}$, respectively. The range of variations is also shown by toolbars for repeated tests. Table 5 provides a summary of the experimental results obtained from triaxial tests. The samples were consolidated at elevated temperatures of 40, 60, and $80^{\circ} \mathrm{C}$ under the confining pressures of 100,500 , and $1000 \mathrm{kPa}$ for 1,3 , and 5 days, which were referred to as "cured samples" in this study. Then, undrained shear

Table 4. The variables in testing program and number of experiments.

\begin{tabular}{|c|c|c|c|c|}
\hline Type of tests & Testing condition & $\begin{array}{c}\text { Consolidation } \\
\text { temperature } \\
\left({ }^{\circ} \mathrm{C}\right)\end{array}$ & $\begin{array}{c}\text { Consolidation } \\
\text { time } \\
\text { (day) }\end{array}$ & $\begin{array}{c}\text { Total } \\
\text { number of } \\
\text { tests }\end{array}$ \\
\hline $\begin{array}{l}\text { Thermal triaxial } \\
\text { compression test }\end{array}$ & $\begin{array}{l}\text { Consolidation at confining pressures of } 100,500 \text {, } \\
\text { and } 1000 \mathrm{kPa} \text { at defined temperature and time. } \\
\text { Undrained shearing at a strain rate of } 0.2 \mathrm{~mm} / \mathrm{min} \\
\text { with record of deviatoric stress, axial strain, and } \\
\text { pore pressure. }\end{array}$ & 40,60, and 80 & 1,3 , and 5 & 24 \\
\hline $\begin{array}{l}\text { Reference thermal } \\
\text { triaxial compression } \\
\text { test }\end{array}$ & $\begin{array}{l}\text { Primary consolidation at confining pressures of } \\
100,500 \text {, and } 1000 \mathrm{kPa} \text { at ambient temperature. } \\
\text { Undrained shearing at a strain rate of } 0.2 \mathrm{~mm} / \mathrm{min} \\
\text { on thermally consolidated samples. }\end{array}$ & 20 & $\begin{array}{c}\text { End of primary } \\
\text { consolidation }\end{array}$ & 3 \\
\hline $\begin{array}{l}\text { Cyclic thermal } \\
\text { triaxial compression } \\
\text { test }\end{array}$ & $\begin{array}{l}\text { Heating from the ambient temperature to } 80^{\circ} \mathrm{C} \\
\text { under a confinement of } 100 \mathrm{kPa} \text { and then, thermal } \\
\text { curing at } 80^{\circ} \mathrm{C} \text { on Days } 1 \text { or } 5 \text {. Again, cooling to } \\
20^{\circ} \mathrm{C} \text { and shearing after thermal equilibrium. }\end{array}$ & $20-80-20$ & 1,5 & 2 \\
\hline $\begin{array}{l}\text { Reference cyclic } \\
\text { thermal triaxial } \\
\text { compression test }\end{array}$ & $\begin{array}{l}\text { Consolidation at confining pressure of } 100 \mathrm{kPa} \text { at } \\
\text { ambient temperature of } 20^{\circ} \mathrm{C} \text { on Days } 1 \text { and } 5 \text { and } \\
\text { shearing. }\end{array}$ & 20 & 1,5 & 2 \\
\hline
\end{tabular}




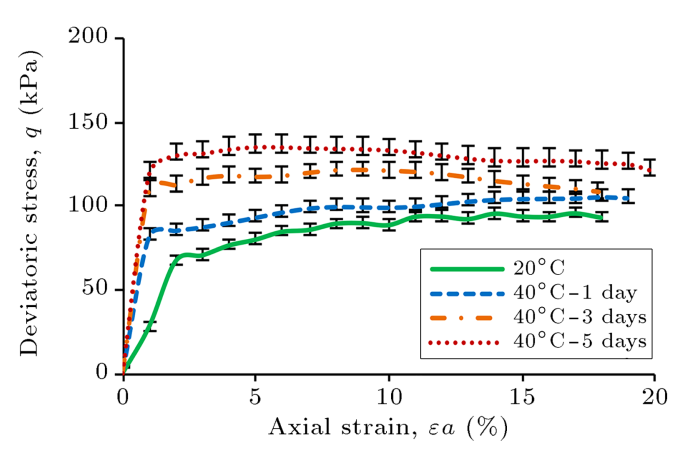

(a)

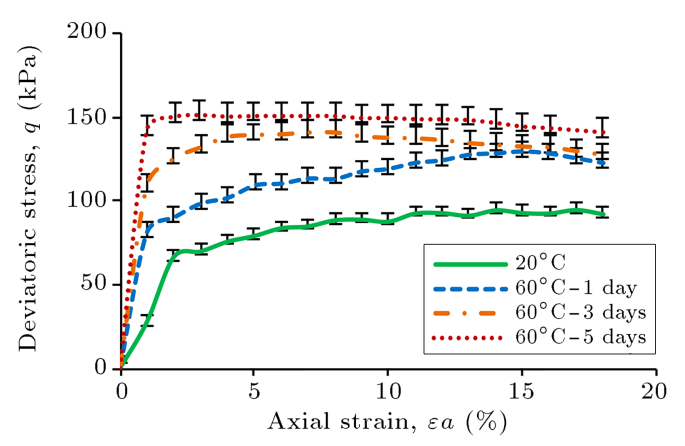

(c)

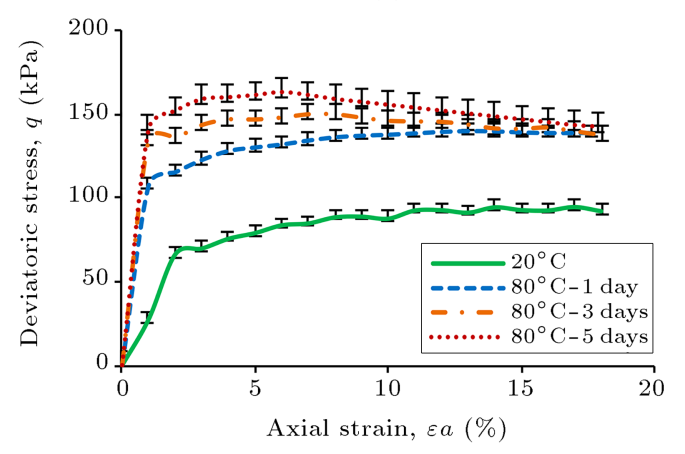

(e)

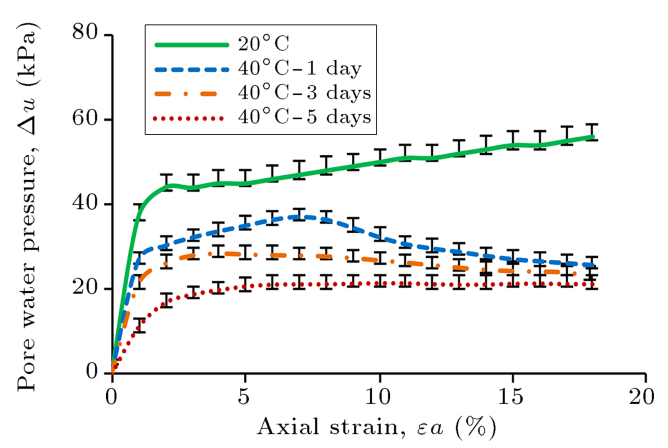

(b)

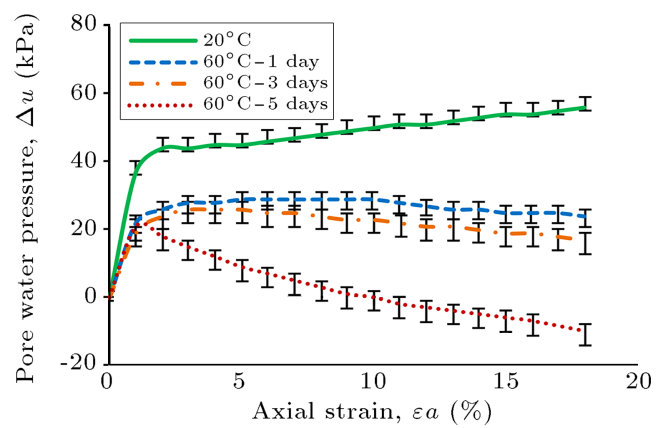

(d)

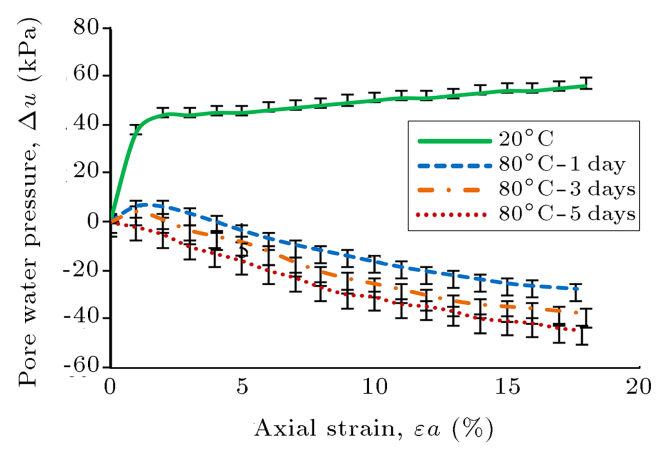

(f)

Figure 4. Triaxial shear behavior of sand-bentonite mixture at different temperatures and curing times for $p_{0}^{\prime}=100 \mathrm{kPa}$ : (a) Deviatoric stress-axial strain at $40^{\circ} \mathrm{C}$, (b) pore pressure-axial strain at $40^{\circ} \mathrm{C}$, (c) deviatoric stress-axial strain at $60^{\circ}$, (d) pore pressure-axial strain at $60^{\circ} \mathrm{C}$, (e) deviatoric stress-axial strain at $80^{\circ} \mathrm{C}$, and (f) pore pressure-axial strain at $80^{\circ} \mathrm{C}$.

loading started on the cured samples. Figures $4-6$ show the results of triaxial tests at the ambient temperature of $20^{\circ} \mathrm{C}$ used for evaluating the curing effects on the shear behavior of soil.

Based on these figures, the samples at the ambient temperature showed smaller shear strength than those consolidated at higher temperatures; however, their shear strength increased upon increasing the confining stress. The trend of behavior for these samples was consistent with the thermal behavior of the normally consolidated clays reported in other studies [32,33].

For the cured samples, the deviatoric stress-axial strain behavior was dependent on the curing time, showing more strength for the samples cured for a longer period. An increase in the shear strength under the influence of temperature can be elaborated through different theories such as oxidization of aluminum and iron during heating and dehydration of iron oxides that created bonds between clay particles [18]. According to Figure 4, a distinct failure point can be observed in the samples with 3 and 5 days of curing; however, samples on Day 1 of curing exhibit a hardening behavior during shear loading. The shear strength of the cured samples increased upon increasing the confining pressures of $500 \mathrm{kPa}$ and $1000 \mathrm{kPa}$, respectively, as shown in Figures 5 and 6 . Based on Figure $7(\mathrm{a})$, the shear strength of the cured samples increased with an increase in both curing time and temperature. Moreover, these samples also failed at the smaller level of strain and experienced softening behavior, as illustrated in Figure 7(b). The behavior trend for the thermally cured samples was much similar to those 


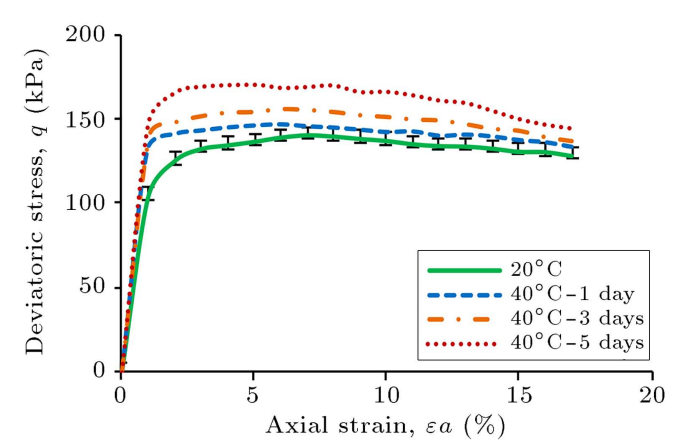

(a)

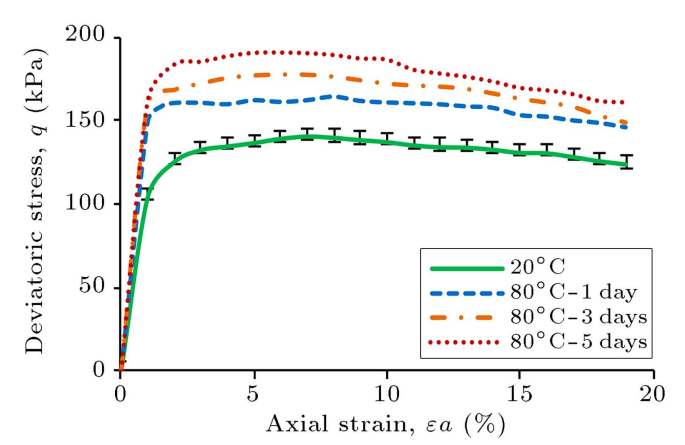

(c)

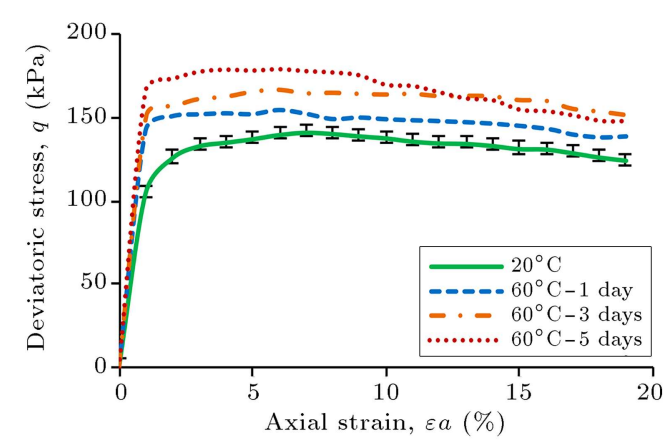

(e)

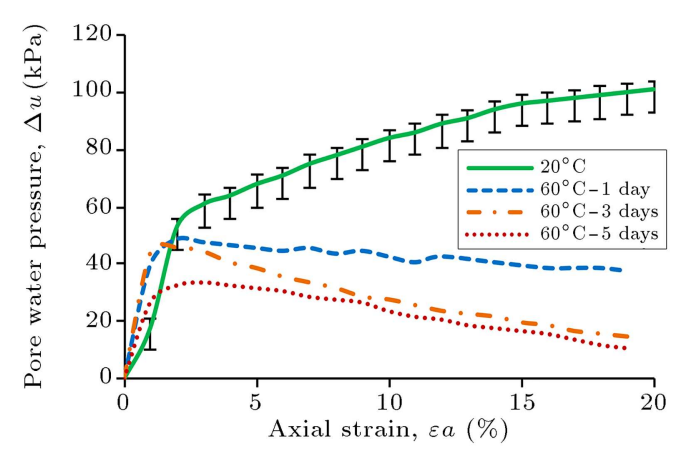

(b)

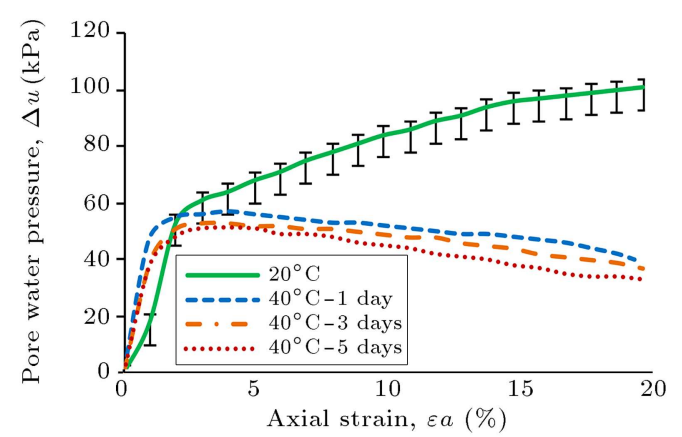

(d)

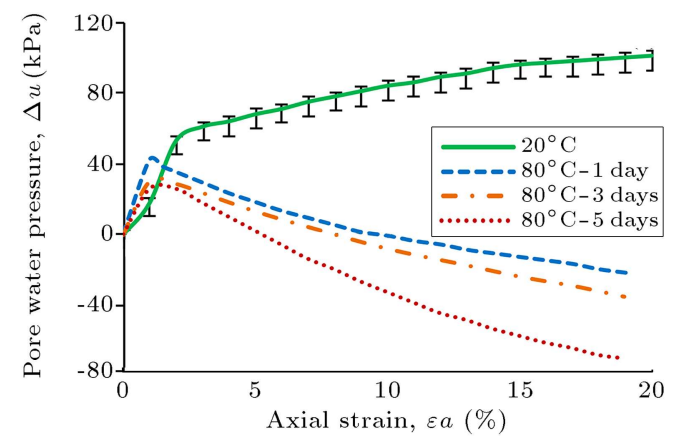

(f)

Figure 5. Triaxial shear behavior of sand-bentonite mixture at different temperatures and curing times for $p_{0}^{\prime}=500 \mathrm{kPa}$ : (a) Deviatoric stress-axial strain at $40^{\circ} \mathrm{C}$, (b) pore pressure-axial strain at $40^{\circ} \mathrm{C}$, (c) deviatoric stress-axial strain at $60^{\circ} \mathrm{C}$,

(d) pore pressure-axial strain at $60^{\circ} \mathrm{C}$, (e) deviatoric stress-axial strain at $80^{\circ} \mathrm{C}$, and (f) pore pressure-axial strain at $80^{\circ} \mathrm{C}$.

for the structured or overconsolidated clays [34] and artificially structured soils [35]. It should be noted that a similar transition of behavior is observed during the consolidation tests on the studied cured sand-bentonite mixture [7].

The effect of the elevated temperature on the elastic modulus is presented in Figure 8. In this figure, the undrained secant modulus is calculated at a shear strength $\left(E_{50}\right)$ of $50 \%$. The toolbars were used to show the range of variations in the repeated tests. The results indicated that the elasticity modulus was higher in the specimens with more curing time and curing temperature than that in the reconstituted ones tested at the ambient temperature. The rate of increase was higher under lower confinements where thermal curing increased the elastic modulus more than three times of its value for the reconstituted samples.
Figures 4-6 indicate the variations of excess pore water pressure with axial strain. The samples consolidated at ambient temperature showed positive pore water pressure; however, the samples cured at elevated temperatures in different curing times and confinements exhibited a different trend of behavior. The induced pore pressure in these samples decreased upon increasing the curing time and curing temperature. For the samples cured at higher temperatures in longer time periods, the pore pressure reached negative values. The samples cured at $80^{\circ} \mathrm{C}$ experienced negative pore pressure at all curing times and confinements; however, at a temperature of $60^{\circ} \mathrm{C}$, negative pore pressures were only observed on Day 5 of curing under a confining stress of $100 \mathrm{kPa}$. The samples consolidated at $40^{\circ} \mathrm{C}$ did not show negative pore pressures at any consolidation time and confinement. This type of behavior is 


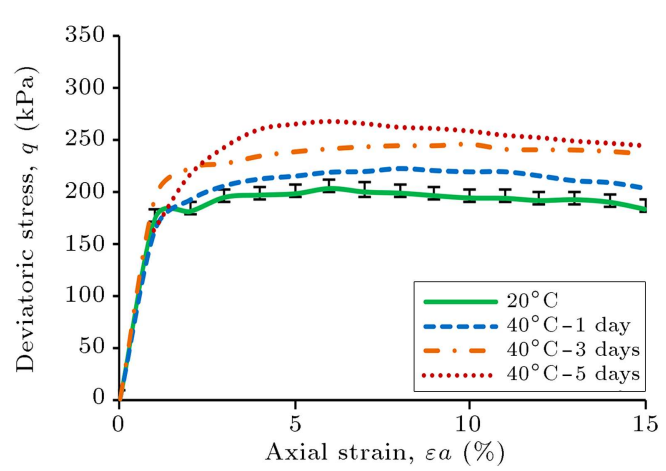

(a)

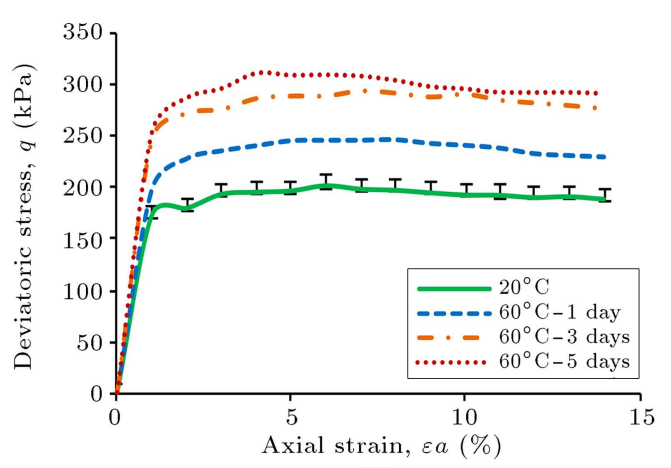

(c)

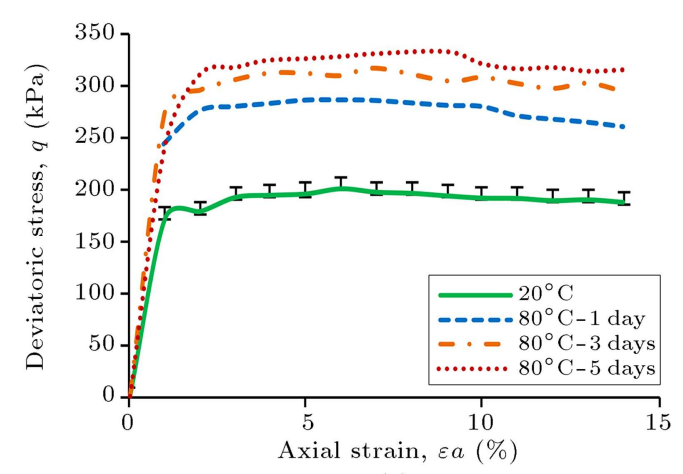

(e)

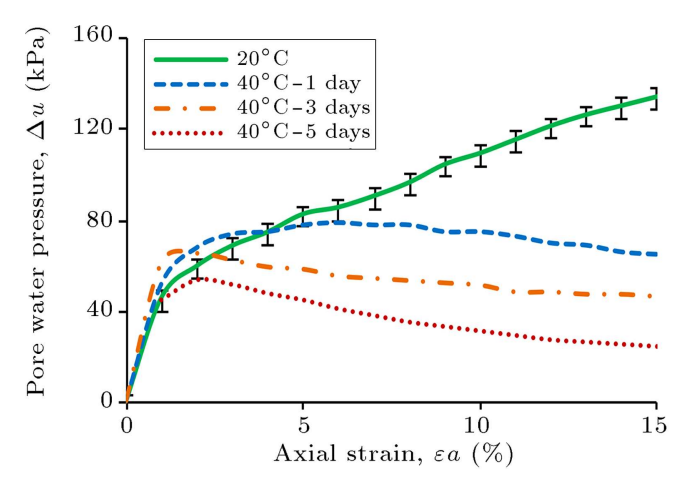

(b)

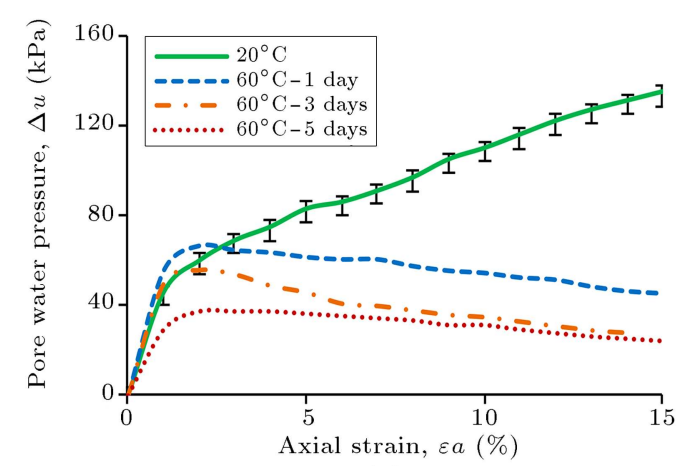

(d)

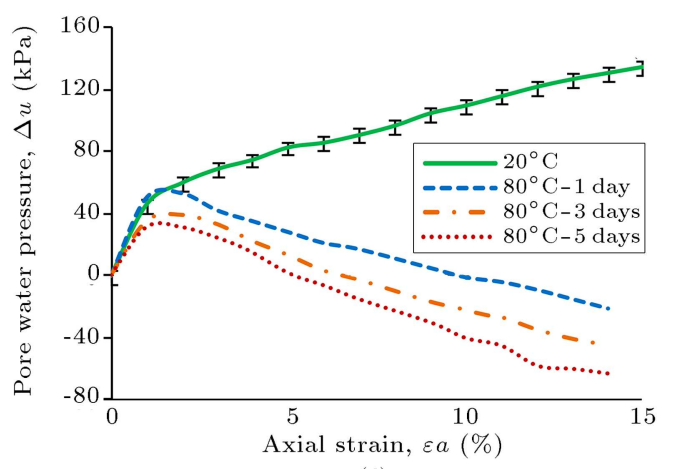

(f)

Figure 6. Triaxial shear behavior of sand-bentonite mixture at different temperatures and curing times for $p_{0}^{\prime}=1000 \mathrm{kPa}$ : (a) deviatoric stress-axial strain at $40^{\circ} \mathrm{C}$, (b) pore pressure-axial strain at $40^{\circ} \mathrm{C}$, (c) deviatoric stress-axial strain at $60^{\circ} \mathrm{C}$, (d) pore pressure-axial strain at $60^{\circ} \mathrm{C}$, (e) deviatoric stress-axial strain at $80^{\circ} \mathrm{C}$, and (f) pore pressure-axial strain at $80^{\circ} \mathrm{C}$.

similar to that of the structured soils, indicating that thermal curing up to the longer periods of time (more than the required time for primary consolidation) results in a behavior transition from the reconstituted to the structured state. In fact, the reduction of excess pore water pressure with temperature for the reference specimens (samples tested at the ambient temperature) is in good agreement with the results obtained from the study on soft Bangkok clay conducted by Abuel-Naga et al. [33]. In addition, the general trend of changes in excess pore water pressure for the samples cured at elevated temperatures is similar to the results from the studies of Rios and Baudet [36] on the cemented silty clay and Amini et al. [37] on the cemented gravely sand categorized as structured soils. Some other soils can also be considered as structured due to cation exchange, flocculation and agglomeration, cementitious hydration, and pozzolanic reaction [38].

As previously illustrated, increasing temperature can make bonding among particles due to the dehydration of iron oxides, which can be referred to as the reason for the observed negative pore pressures. Since it is a time-dependent procedure [39], the induced negative pore pressure is more apparent as curing time increases.

\subsection{Stress path and yield surface evolution}

Total Stress Path (TSP) and Effective Stress Path (ESP) for the samples under confining pressures of 100 , 500 , and $1000 \mathrm{kPa}$ are presented in Figure 9. The stress 
Table 5. Summary of thermal triaxial compression test results.

\begin{tabular}{|c|c|c|c|c|c|c|c|c|c|c|c|}
\hline \multirow[b]{2}{*}{$\begin{array}{l}\text { Test } \\
\text { no. }\end{array}$} & \multirow[b]{2}{*}{$\begin{array}{c}\text { Consolidation } \\
\text { temperature } \\
\left({ }^{\circ} \mathrm{C}\right)\end{array}$} & \multirow[b]{2}{*}{$\begin{array}{c}\text { Consolidation } \\
\text { time } \\
(\text { day })\end{array}$} & \multirow[b]{2}{*}{$\begin{array}{c}\text { Confining } \\
\text { stress } \\
(\mathbf{k P a})\end{array}$} & \multicolumn{2}{|c|}{$\begin{array}{l}\text { Deviatoric } \\
\text { stress } \\
(\mathbf{k P a})\end{array}$} & \multicolumn{2}{|c|}{$\begin{array}{c}\text { Mean } \\
\text { effective } \\
\text { stress } \\
(\mathbf{k P a})\end{array}$} & \multicolumn{2}{|c|}{$\begin{array}{c}\text { Axial } \\
\text { strain } \\
(\%)\end{array}$} & \multicolumn{2}{|c|}{$\begin{array}{c}\text { Pore } \\
\text { pressure } \\
(\mathbf{k P a})\end{array}$} \\
\hline & & & & $\begin{array}{c}\text { At } \\
\text { peak }\end{array}$ & $\begin{array}{c}\text { At } \\
\text { critical } \\
\text { state }\end{array}$ & $\begin{array}{c}\text { At } \\
\text { peak }\end{array}$ & $\begin{array}{c}\text { At } \\
\text { critical } \\
\text { state }\end{array}$ & $\begin{array}{c}\text { At } \\
\text { peak }\end{array}$ & $\begin{array}{c}\text { At } \\
\text { critical } \\
\text { state }\end{array}$ & $\begin{array}{c}\text { At } \\
\text { peak }\end{array}$ & $\begin{array}{c}\text { At } \\
\text { critical } \\
\text { state }\end{array}$ \\
\hline 1 & 20 & - & 100 & 93 & 90 & 80 & 73 & 11 & 20 & 51 & 57 \\
\hline 2 & 40 & 1 & 100 & 98 & 105 & 96 & 110 & 7 & 19 & 37 & 25 \\
\hline 3 & 60 & 1 & 100 & 111 & 123 & 108 & 117 & 6 & 18 & 29 & 24 \\
\hline 4 & 80 & 1 & 100 & 129 & 139 & 143 & 174 & 4 & 18 & 0 & -28 \\
\hline 5 & 40 & 3 & 100 & 119 & 108 & 112 & 113 & 7 & 18 & 28 & 23 \\
\hline 6 & 60 & 3 & 100 & 139 & 125 & 120 & 125 & 5 & 19 & 26 & 17 \\
\hline 7 & 80 & 3 & 100 & 143 & 135 & 151 & 184 & 3 & 19 & -3 & -39 \\
\hline 8 & 40 & 5 & 100 & 135 & 121 & 124 & 120 & 5 & 20 & 21 & 21 \\
\hline 9 & 60 & 5 & 100 & 151 & 136 & 135 & 156 & 3 & 20 & 15 & -11 \\
\hline 10 & 80 & 5 & 100 & 160 & 143 & 163 & 193 & 3 & 18 & -10 & -45 \\
\hline 11 & 20 & - & 500 & 140 & 124 & 469 & 440 & 8 & 20 & 78 & 101 \\
\hline 12 & 40 & 1 & 500 & 146 & 129 & 495 & 503 & 7 & 20 & 54 & 40 \\
\hline 13 & 60 & 1 & 500 & 154 & 139 & 506 & 508 & 6 & 19 & 45 & 38 \\
\hline 14 & 40 & 3 & 500 & 156 & 128 & 500 & 506 & 6 & 20 & 52 & 37 \\
\hline 15 & 60 & 3 & 500 & 165 & 151 & 516 & 535 & 5 & 19 & 39 & 15 \\
\hline 16 & 80 & 3 & 500 & 172 & 147 & 533 & 586 & 3 & 20 & 24 & -37 \\
\hline 17 & 40 & 5 & 500 & 170 & 135 & 506 & 512 & 5 & 20 & 51 & 33 \\
\hline 19 & 60 & 5 & 500 & 179 & 148 & 527 & 538 & 4 & 19 & 33 & 11 \\
\hline 19 & 80 & 5 & 500 & 183 & 159 & 535 & 627 & 2 & 20 & 26 & -74 \\
\hline 20 & 20 & - & 1000 & 202 & 183 & 981 & 926 & 8 & 15 & 86 & 135 \\
\hline 21 & 40 & 1 & 1000 & 223 & 204 & 996 & 1003 & 8 & 15 & 78 & 65 \\
\hline 22 & 40 & 3 & 1000 & 242 & 235 & 1027 & 1032 & 7 & 16 & 54 & 46 \\
\hline 23 & 60 & 3 & 1000 & 294 & 276 & 1042 & 1064 & 6 & 14 & 56 & 28 \\
\hline 24 & 80 & 3 & 1000 & 314 & 296 & 1066 & 1144 & 4 & 14 & 39 & -45 \\
\hline 25 & 40 & 5 & 1000 & 267 & 240 & 1035 & 1058 & 5 & 17 & 54 & 22 \\
\hline 26 & 60 & 5 & 1000 & 312 & 268 & 1067 & 1068 & 4 & 17 & 37 & 21 \\
\hline 27 & 80 & 5 & 1000 & 333 & 315 & 1080 & 1169 & 3 & 13 & 31 & -64 \\
\hline
\end{tabular}

paths were plotted at 40,60 , and $80^{\circ} \mathrm{C}$ on Days 1,3 , and 5 of curing and they were compared with those of the samples tested at ambient temperature. It was concluded that an increase in the curing temperature at a constant confinement shifted ESP towards the right side of TSP due to the induced negative excess pore water pressure. This trend was more evident at a confining pressure of $100 \mathrm{kPa}$ (Figure $9(\mathrm{a})-(\mathrm{c})$ ). Moreover, an increase in the confining stress at a constant temperature shifted ESP towards the left hand of TSP due to the reduction of negative pore pressures. This type of behavior can be observed more clearly for the samples cured at a temperature of $80^{\circ} \mathrm{C}$ (Figures 9(c), (f), and (i)).

Figure 10 shows the comparison of the slope of the critical state line $\left(M_{T}\right)$ at different curing times and temperatures in the present study and that in others. According to the results, $M_{T}$ which is also related to the critical state friction angle slightly varies based on both curing time and curing temperature. 


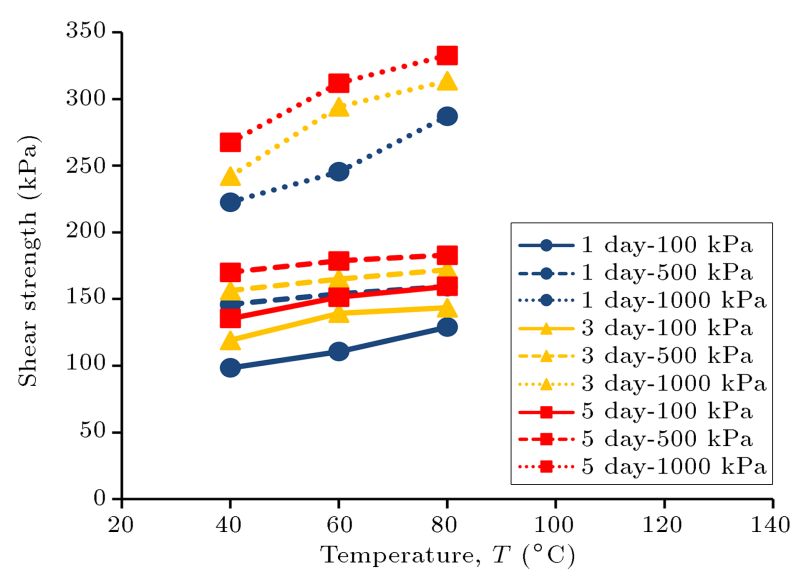

(a)

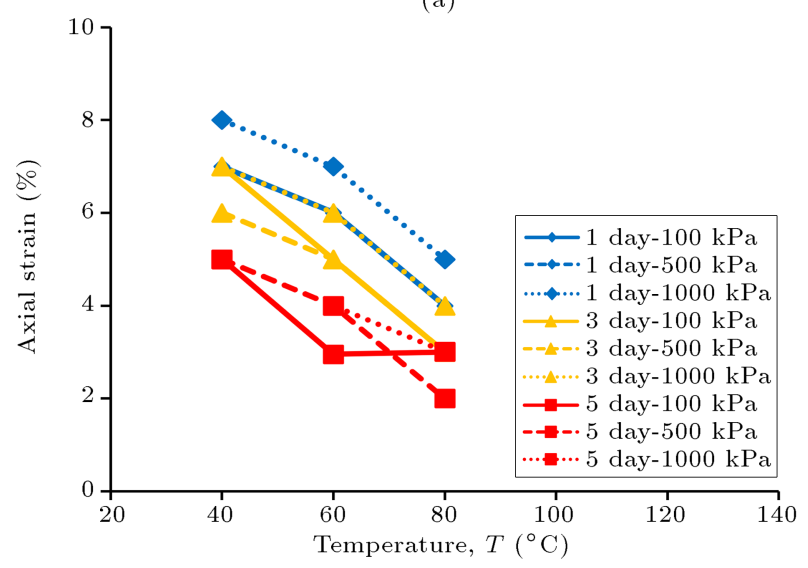

(b)

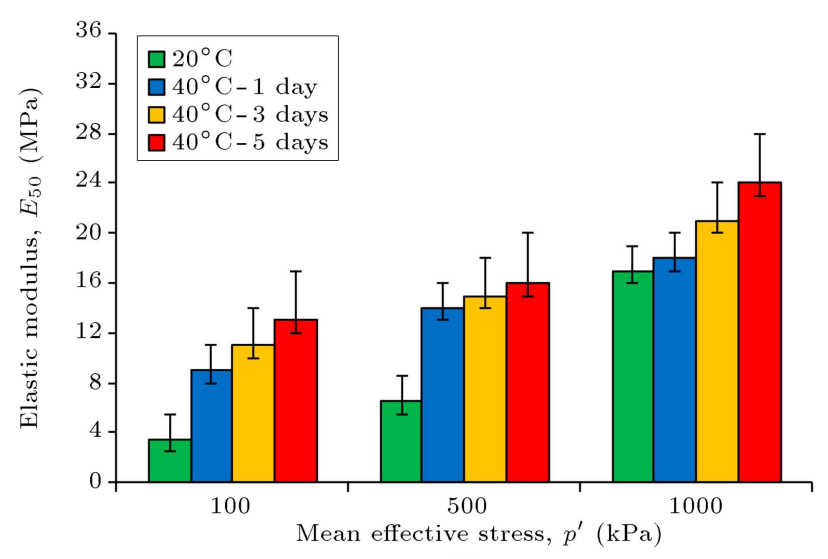

(a)

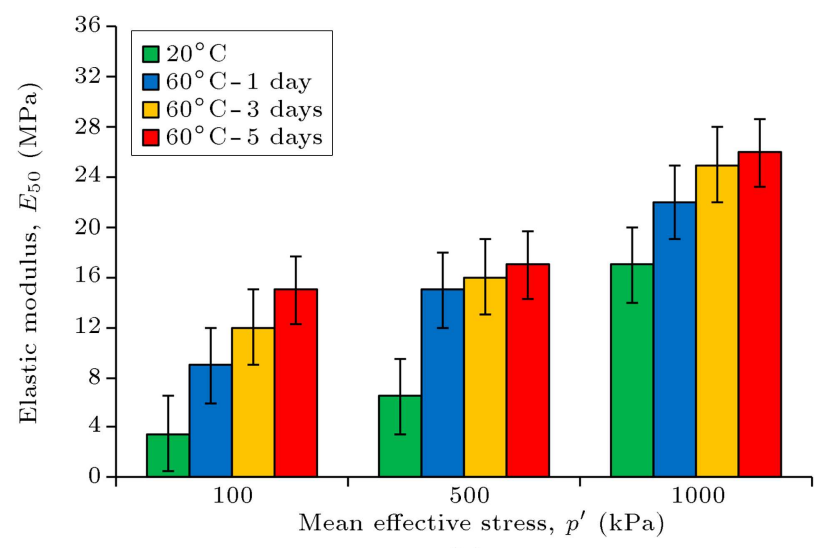

(b)

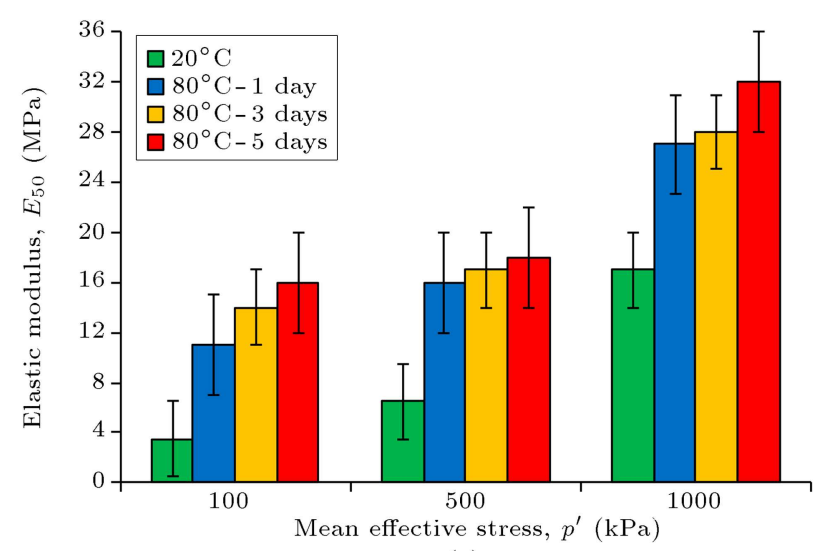

(c)

Figure 8. Effect of temperature and curing time on the secant modulus at $50 \%$ of peak strength: (a) $\mathrm{T}=40^{\circ} \mathrm{C}$, (b) $\mathrm{T}=60^{\circ} \mathrm{C}$, and (c) $\mathrm{T}=80^{\circ} \mathrm{C}$.

\section{Discussion}

In order to elaborate the effect of curing process on the behavior of the sand-bentonite mixture, a few specimens were subjected to the cycles of thermal paths. To prove this hypothesis, two samples were exposed to thermal paths of $20^{\circ} \mathrm{C}-80^{\circ} \mathrm{C}-20^{\circ} \mathrm{C}$ at the confining pressure of $100 \mathrm{kPa}$. First, the temperature increased from $20^{\circ} \mathrm{C}$ to $80^{\circ} \mathrm{C}$ and remained constant to cure on Days 1 or 5 . Then, the temperature decreased figure, at all temperatures, an increase in the curing time slightly increased the size of the yield surface. 


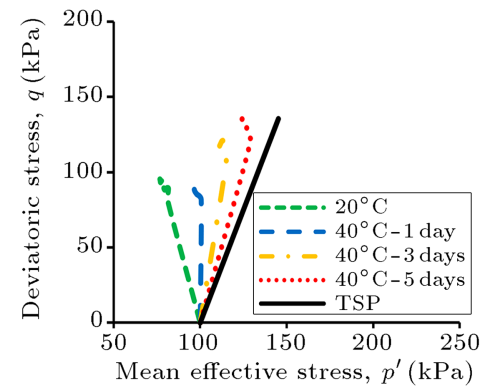

(a)

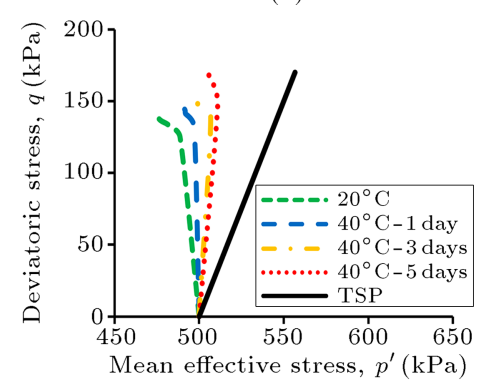

(d)

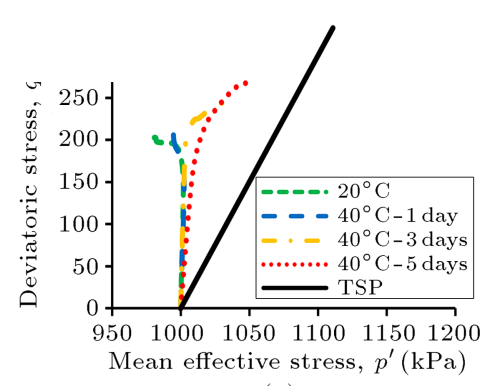

(g)

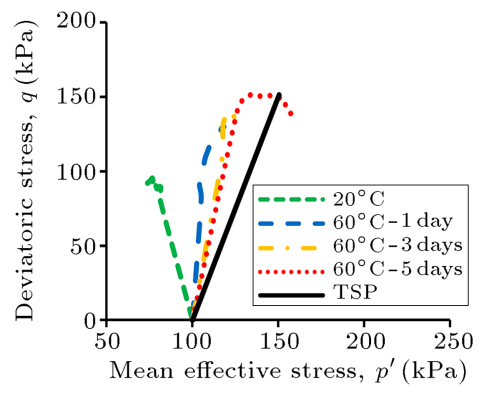

(a)

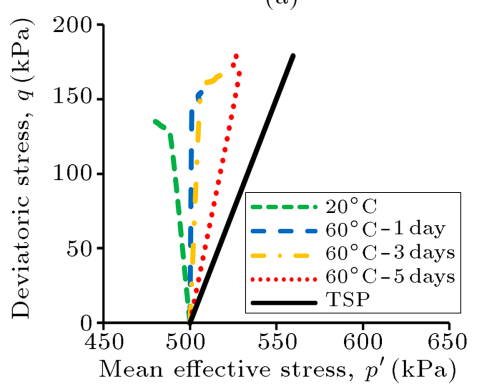

(e)

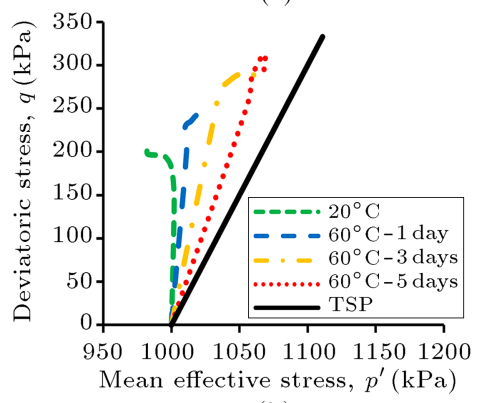

(h)

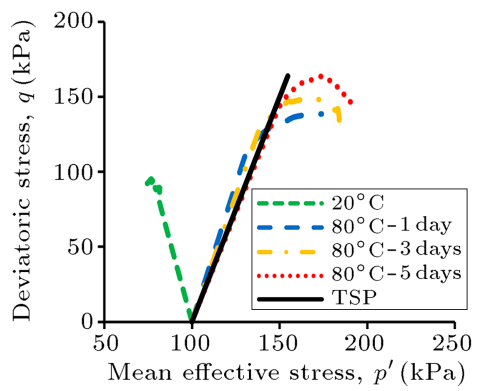

(c)

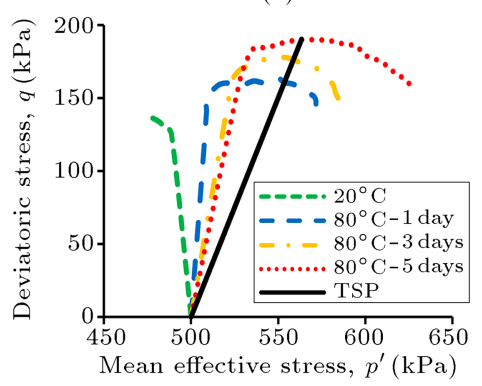

(f)

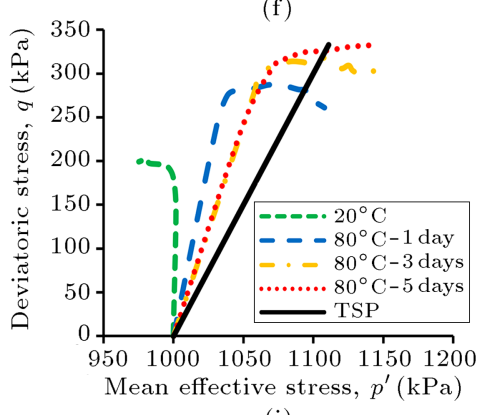

(i)

Figure 9. Total and effective stress paths of sand-bentonite mixtures at different temperatures and curing times:

(a) $p_{0}^{\prime}=100 \mathrm{kPa}, T=40^{\circ} \mathrm{C}$, (b) $p_{0}^{\prime}=100 \mathrm{kPa}, T=60^{\circ} \mathrm{C}$, (c) $p_{0}^{\prime}=100 \mathrm{kPa}, T=80^{\circ} \mathrm{C},(\mathrm{d}) p_{0}^{\prime}=500 \mathrm{kPa}, T=40^{\circ} \mathrm{C}$,

(e) $p_{0}^{\prime}=500 \mathrm{kPa}, T=60^{\circ} \mathrm{C}$, (f) $p_{0}^{\prime}=500 \mathrm{kPa}, T=80^{\circ} \mathrm{C}$, (g) $p_{0}^{\prime}=1000 \mathrm{kPa}, T=40^{\circ} \mathrm{C},(\mathrm{h}) p_{0}^{\prime}=1000 \mathrm{kPa}, T=60^{\circ} \mathrm{C}$, and

(i) $p_{0}^{\prime}=1000 \mathrm{kPa}, T=80^{\circ} \mathrm{C}$.

to $20^{\circ} \mathrm{C}$ and the samples were sheared after thermal equilibrium. The obtained results were compared with those from the tests on samples at ambient temperature

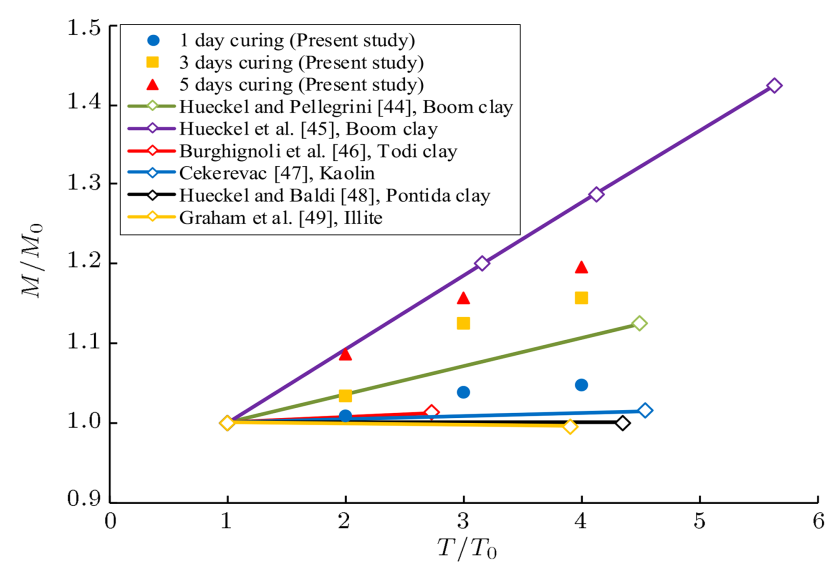

Figure 10. Effect of temperature on the slope of critical state line for different clays. $\left(20^{\circ} \mathrm{C}\right)$ without any thermal cycles in Figure 12.

Variation in the shear strength of these samples with temperature is shown in Figure 12(a) for an initial confinement of $100 \mathrm{kPa}$ and an increase in strength of samples during the curing cycle can be clearly observed. The sample with Day 5 of curing reached greater shear strength than the sample on Day 1 of curing. In case the samples are cooled again to ambient temperature, the shear strength of the sample on Day 5 of curing is about $62 \%$ greater than the initial strength; however, the shear strength for the sample with Day 1 of curing increased by about $43 \%$.

Figure 12(b) plots the variations of Skempton's pore pressure coefficient, $A$ (associated to the peak shear strength), with temperature at a confining pressure of $100 \mathrm{kPa}$. In this figure, changes in the pore pressure during the curing procedure can be investigated. When the value of $A$ was about 0.6 for the sample sheared at the ambient temperature of $20^{\circ} \mathrm{C}$, it decreased to about zero for the sample cured on Day 1 


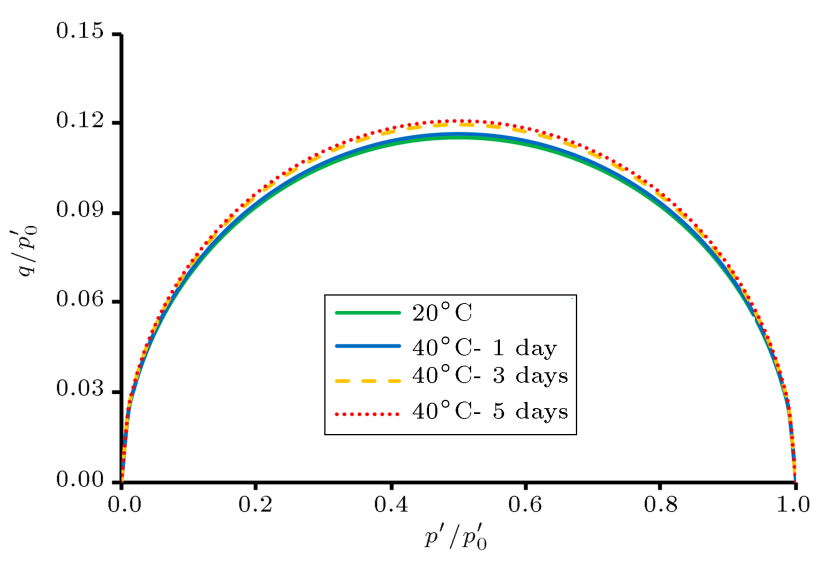

(a)

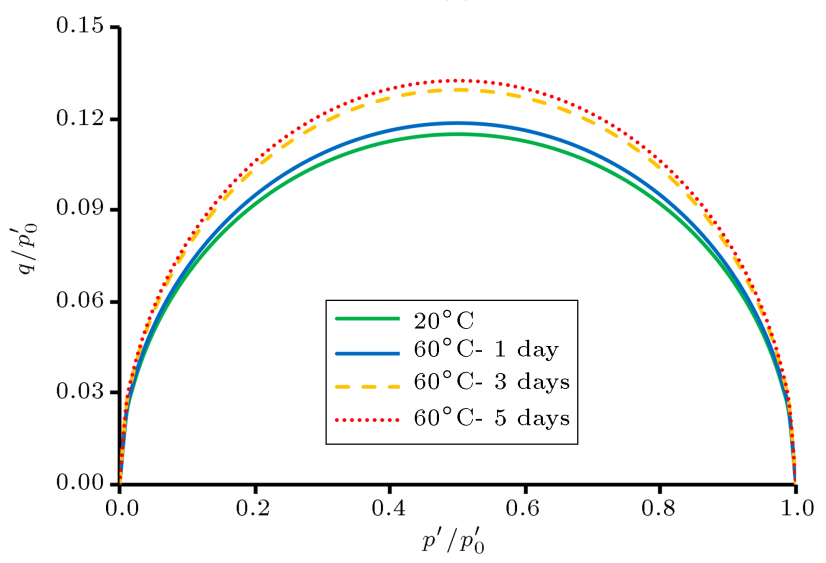

(b)

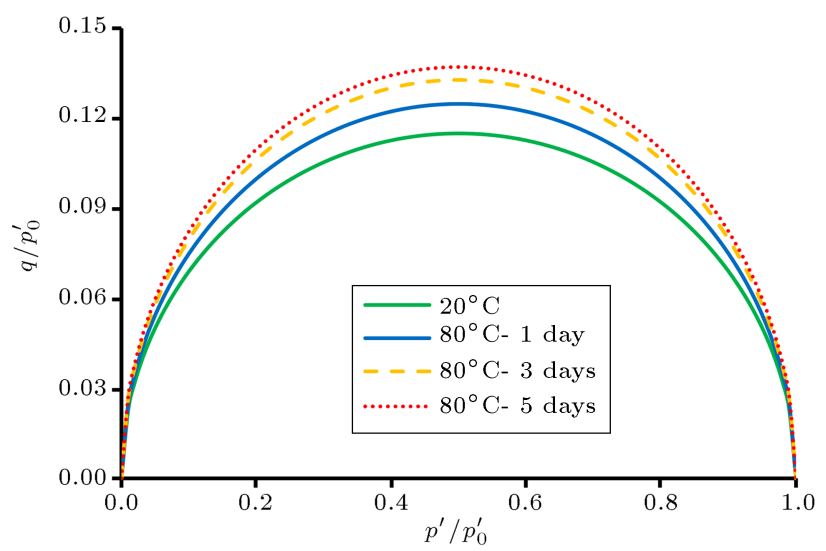

(c)

Figure 11. Effect of curing time and temperature on the yield surface of sand-bentonite mixture at $p_{0}^{\prime}=100 \mathrm{kPa}$ : (a) 1 day curing, (b) 3 days curing, and (c) 5 days curing.

at $80^{\circ} \mathrm{C}$ and then, the sample was cooled to $20^{\circ} \mathrm{C}$, or even to a negative value for the sample that has been cured for 5 days at $80^{\circ} \mathrm{C}$ and was cooled back to the ambient temperature.

Based on the cyclic temperature experiments, the effect of thermal curing on the shear response of sand-bentonite mixture was clearly demonstrated. It can also explain the formation of a quasi-structured behavior for the samples during thermal curing. It

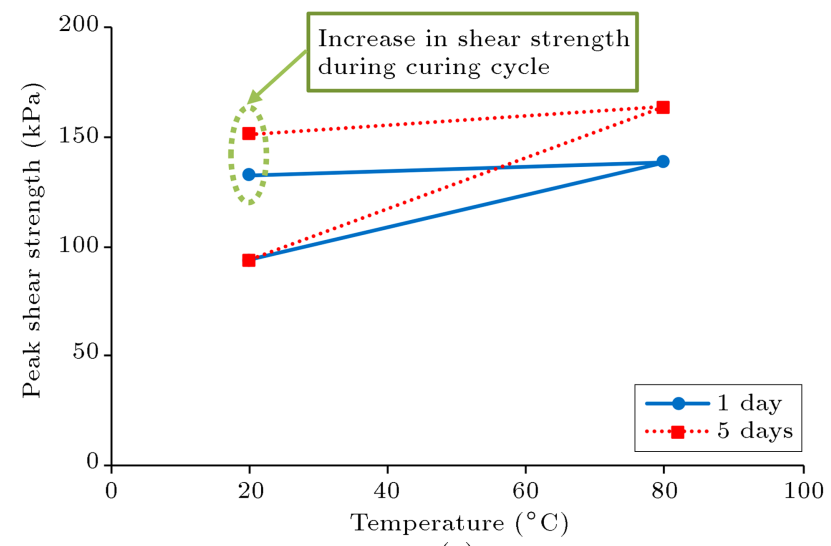

(a)

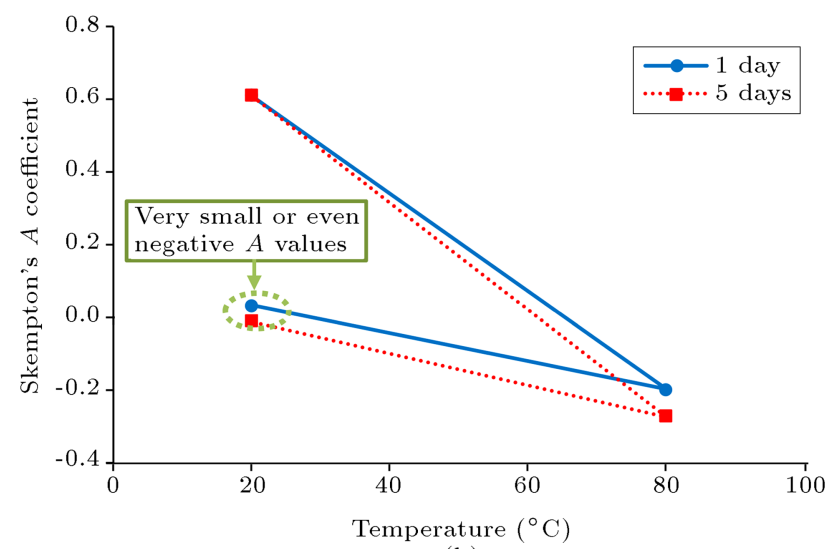

(b)

Figure 12. Variation of shear characteristics for the temperature cycle of $20^{\circ} \mathrm{C}-80^{\circ} \mathrm{C}-20^{\circ} \mathrm{C}$ at a confining pressure of $100 \mathrm{kPa}$ : (a) Shear strength and (b)

Skempton's A coefficient.

should be noted that in the present study, the changes in behavior were investigated for only short curing times; however, it can be visualized that when the soil is subjected to temperature for a long period, how would be the changes of the behavior after cooling the system to the ambient temperature. This can be helpful in characterization of the soils and sites that have been previously used for thermal structures.

In order to investigate thermal curing effects on the structure of sand-bentonite mixture, SEM studies have been performed. A number of images have been taken from the studied soil cured at different times and temperatures. It should be noted again that the used range of temperatures in the present study $\left(20^{\circ} \mathrm{C}\right.$ to $\left.80^{\circ} \mathrm{C}\right)$ does not influence the composition of the tested sand-bentonite mixture. This behavior has been explained previously by Wang et al. [41-50] who carried out a detailed investigation on the dehydration process in clays. They showed that dehydration of water layers would lead to greater bonding between particles. However, mineral destruction of clay and formation of new silicate crystals occur at temperatures higher than $500^{\circ} \mathrm{C}$. 


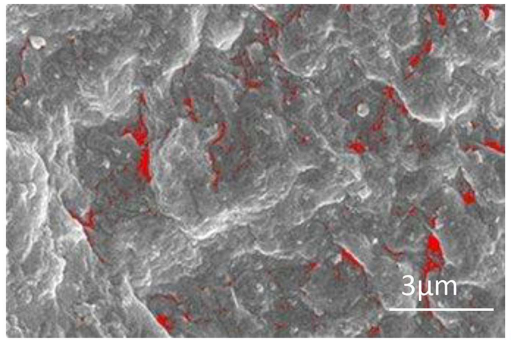

(a)

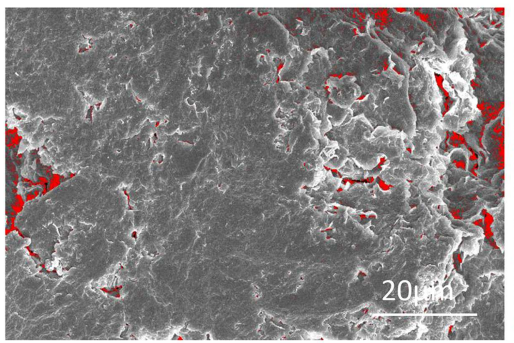

(d)

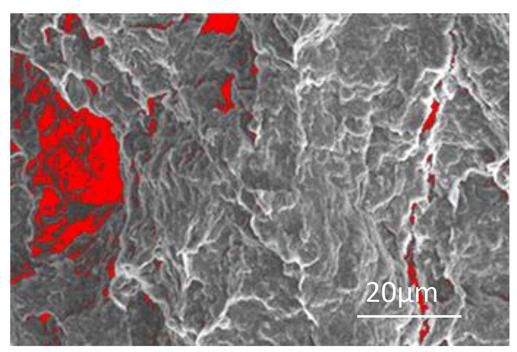

(g)

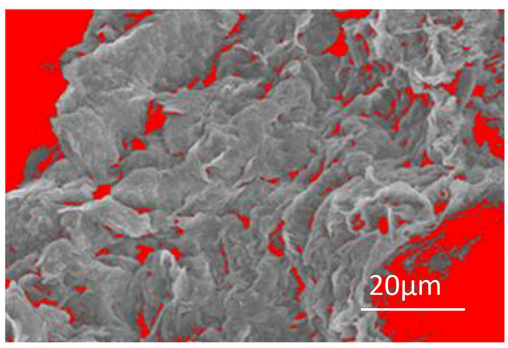

(j)

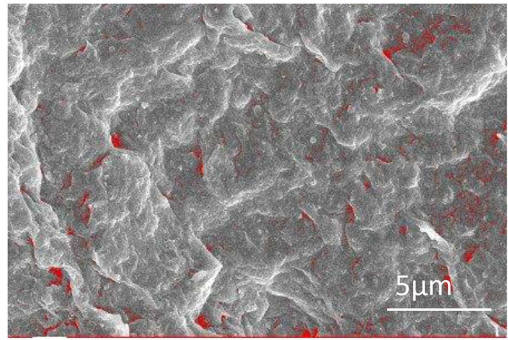

(b)

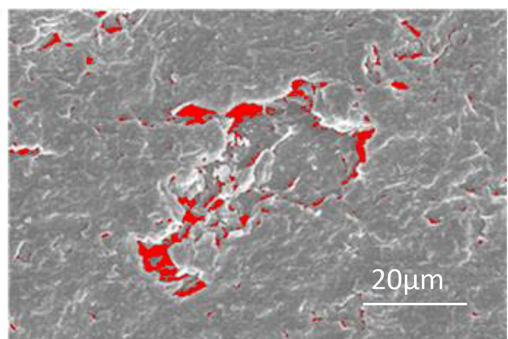

(e)

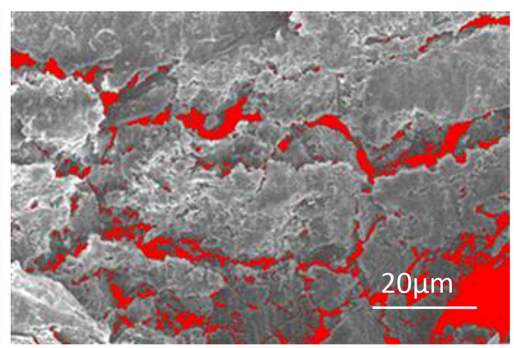

(h)

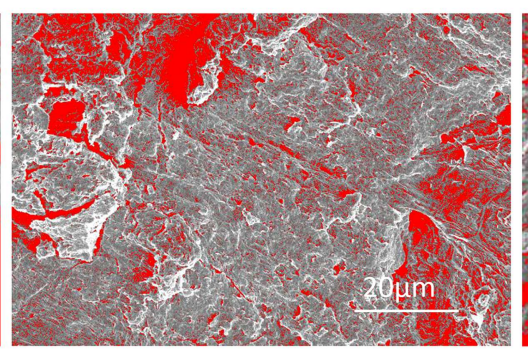

(k)

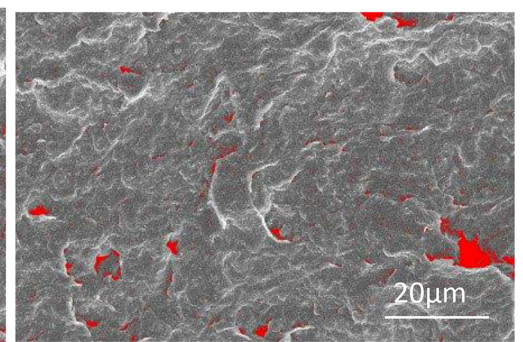

(c)

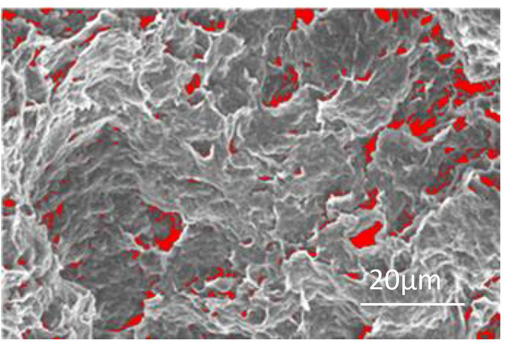

(f)

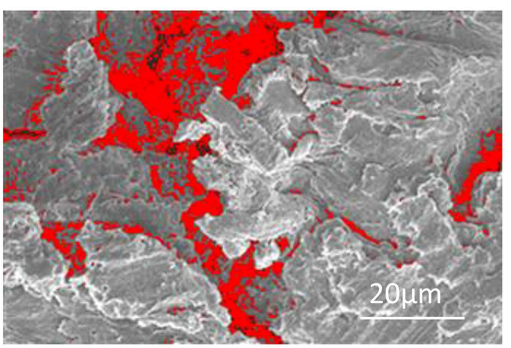

(i)

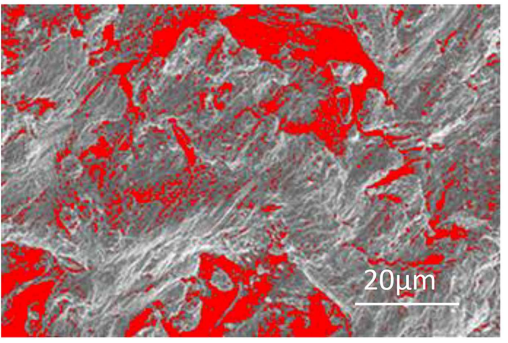

(1)

Figure 13. Scanning Electron Microscopy (SEM) images of the studies soil at different curing times and temperatures: (a) $20^{\circ} \mathrm{C}$, no curing, (b) $20^{\circ} \mathrm{C}$, no curing, (c) $20^{\circ} \mathrm{C}$, no curing, (d) $40^{\circ} \mathrm{C}, 1$ day, (e) $40^{\circ} \mathrm{C}, 3$ days, (f) $40^{\circ} \mathrm{C}, 5$ days, (g) $60^{\circ} \mathrm{C}, 1$ day, (h) $60^{\circ} \mathrm{C}, 3$ days, (i) $60^{\circ} \mathrm{C}, 5$ days, (j) $80^{\circ} \mathrm{C}, 1$ day, (k) $80^{\circ} \mathrm{C}, 3$ days, and (l) $80^{\circ} \mathrm{C}, 5$ days.

Table 6. The changes in the void ratio of sand-bentonite mixture during pre-curing.

\begin{tabular}{ccccccccccc}
\hline Curing temperature $\left({ }^{\circ} \mathbf{C}\right)$ & $\mathbf{2 0}$ & & $\mathbf{4 0}$ & \multicolumn{3}{c}{$\mathbf{6 0}$} & \multicolumn{3}{c}{$\mathbf{8 0}$} \\
\hline Curing time (day) & 0 & 1 & 3 & 5 & 1 & 3 & 5 & 1 & 3 & 5 \\
Void ratio (\%) & 1.6 & 1.8 & 2.4 & 3.6 & 5.6 & 9.0 & 14.5 & 16.9 & 17.7 & 18.3 \\
\hline
\end{tabular}

The effects of thermal curing on the sandbentonite mixture considering the time factor are depicted in Figure 13. The void ratio of the cured samples at elevated temperatures is obtained using Image $J$ software and is highlighted in red in Figure 13. The void ratio of samples in different pre-curing conditions has been determined by dividing the highlighted area to the total area in each figure and is depicted in Table 6 . Based on the results, the void ratio of samples increases with curing time and curing temperature from $1.6 \%$ for 
the sample at the ambient temperature to $18.3 \%$ for the pre-cured sample at $80^{\circ} \mathrm{C}$ on Day 5 .

The increase in void ratio during the pre-curing process confirms the increase in water content of the saturated sample and reduction of its unit weight. This leads to the increase in permeability of mixture which is in line with results of Shirasb et al. [7] who reported an increase in permeability of pre-cured samples using the values obtained indirectly from consolidation tests on the same soil. These findings are in agreement with those by Attah and Etim [6] who also reported changes in the structure of tropical soils due to the thermal preheating process.

\section{Conclusions}

A comprehensive experimental program was planned in this study to evaluate the effects of thermal curing on the shear behavior of a sand-bentonite mixture. The following remarks can be made:

- Based on the deviatoric stress-axial strain diagrams for different temperatures, it was found that the shear strength of sand-bentonite mixture increased upon increasing the curing time and temperature; however, the strain associated with the peak shear strength decreased by curing the sample more. The excess pore water pressure was also reduced by increasing the curing parameters (time and temperature) from the positive to negative values. The trend of variations in the excess pore water pressure at higher temperatures was similar to those of the structured clays;

- The effective stress path of the tested specimens at each temperature was shifted towards the left side of the total stress path upon increase in the confining pressure. However, as the time or temperature of thermal curing increased at a constant confinement, the effective stress path was shifted to the right side of total stress path;

- The slope of the critical state line increased slightly with curing time and temperature. In addition, the undrained secant elastic modulus increased with curing of the soil;

- According to the cyclic thermal paths, after curing at higher temperatures and returning to the ambient value, the induced pore pressure and deviatoric stress are not the same as the initial condition. The samples had a greater shear strength while pore pressure dropped to smaller values, similar to the trend of behavior which is usually observed for structured soils. In the present study, it was inferred as a quasi-structured behavior of the soil induced by thermal curing;
- Based on the results of Scanning Electron Microscopy (SEM), the void ratio of samples increased with increase in curing time and curing temperature;

- Based on the results of the present study, although the shear strength of sand-bentonite mixture improves due to the pre-curing process, the increase in its brittleness and the reduction of its plasticity and unit weight should be crucially controlled. Moreover, increase in the void ratio of mixture during the pre-curing process is an indicator of the increase in its permeability. Due to the important role of buffer layer as an impermeable barrier in HLW disposal sites, the values should be controlled carefully based on standards and provisions.

\section{Acknowledgement}

Testing was done at the Soil Mechanics Laboratory in the School of Engineering of Kharazmi University, Iran. The authors would like to thank the effort of all the technicians who made assistance during testing. The constructive comments of Antonio Gens and Enrique Romero from UPC, Spain are also gratefully appreciated.

\section{References}

1. Ghaebi. H., Bahadori, M.N., and Saidi, M.H. "Different operational alternatives of aquifer thermal energy storage system for cooling and heating of a residential complex under various climatic conditions in Iran", Scientia Iranica, 26(3), pp. 1281-1292 (2019).

2. Chen, W.Z., Ma, Y.S., Yu, H.D., et al. "Effects of temperature and thermally-induced microstructure change on hydraulic conductivity of Boom Clay", Journal of Rock Mechanics and Geotechnical Engineering, 9(3), pp. 383-395 (2017).

3. Tsuchida, T., Kobayashi, M., and Mizukami, J. "Effect of aging of marine clay and its duplication by high temperature consolidation", Soils and Foundations, 31(4), pp. 133-147 (1991).

4. Towhata, I., Kuntiwattanaku, P., Seko, I., et al. "Volume change of clays induced by heating as observed in consolidation tests", Soils and Foundations, 33(4), pp. 170-183 (1993).

5. Pusch, R. and Guven, N. "Electron microscopic examination of hydrothermally treated bentonite clay", Engineering Geology, 28, pp. 303-314 (1990).

6. Attah, I.C. and Etim, R.K. "Experimental investigation on the effects of elevated temperature on geotechnical behaviour of tropical residual soils", SN Applied Sciences, 2(370) (2020). https://doi.org/10.1007/s42452-020-2149-x

7. Shirasb, A., Hamidi, A., and Ahmadi, M.M. "Consolidation characteristics of a thermally cured sandbentonite mixture", SN Applied Sciences, 2(6) (2020). https://doi.org/10.1007/s42452-020-2932-8 
8. Tabarsa, A. and Lashkarbolok, M. "A numerical investigation of the effect of the temperature on the seepage calculation", Scientia Iranica, 25(4), pp. 1907-1915 (2018).

9. Avci, E. "The effect of different curing temperatures on engineering properties of chemically grouted sands", Scientia Iranica, 27(3), pp. 1144-1161 (2020).

10. Gens, A., Vaunat, J., Ggaritte, B., et al. "In situ behaviour of a stiff layered clay subject to thermal loading: observations and interpretation", Geotechnique, 57(2), pp. 208-227 (2007).

11. Ajdari, M. and Bahm Yari, H. "Oedometric response of an artificially prepared sand-bentonite mixture improved by potassium silicate", Scientia Iranica, A, 22(2), pp. 367-372 (2015).

12. Cabalar, A.F. "Influence of grain shape and gradation on the shear behavior of sand mixtures", Scientia Iranica, 25(6), pp. 3101-3109 (2018).

13. Liu, J.F., Song, S.B., Ni, H.Y., et al. "Research on the gas migration properties in a saturated bentonite/sand mixture under flexible boundary condition", Soils and Foundations, 58(1), pp. 97-109 (2018).

14. Li, H.F., Chen, M.Q., Fu, B.A., et al. "Evaluation on the thermal and moisture diffusion behavior of sand/bentonite", Applied Thermal Energy, 151, pp. 55-65 (2019).

15. Dixon, D.A., Gray, M.N., and Thomasa, W. "A study of the compaction properties of potential clay-sand buffer mixtures for use in nuclear fuel waste disposal", Engineering Geology, 21, pp. 247-255 (1985).

16. Rawat, A., Baille, W., and Tripathy, S. "Swelling behavior of compacted bentonite-sand mixture during water infiltration", Engineering Geology, 257, 105141 (2019). https://doi.org/10.1016/j.enggeo.2019.05.018

17. Jarad, N., Cuisinier, O., and Masrouri, F. "Effect of temperature and strain rate on the consolidation behavior of compacted clayey soils", European Journal of Environmental and Civil Engineering, 23(7), pp. 789-806 (2017).

18. White, R.E., Principles and Practice of Soil Science, Blackwell Publishing (2006).

19. Fookes, P.G., Tropical Residual Soils, The Geological Society, London (1997).

20. de La Fuente, S., Cuadros, J., Fiore, S., et al. "Electron microscopy study of volcanic tuff alteration to illitesmectite under hydrothermal conditions", Clays and Clay Minerals, 48(3), pp. 339-350 (2000).

21. Wersin, P., Johnson, L.H., and McKinley, I.G. "Performance of the bentonite barrier at temperatures beyond $100^{\circ} \mathrm{C}$ : a critical review", Physics and Chemistry of the Earth, 32(8), pp. 780-788 (2006).

22. Estabragh, A.R., Khosravi, F., and Javadi, A.A. "Effect of thermal history on the properties of bentonite", Environmental Earth Sciences, 75, 657 (2016).

23. ASTM D-4546, Annual Book of ASTM Standards, Soils and Rock Division, West Conshohocken, USA (2003).
24. Erzin, Y. and Erol, O. "Correlations for quick prediction of swell pressures", Electronic Journal of Geotechnical Engineering, 9(1), p. 476 (2004).

25. Komine, H. and Nobuhide, O. "Experimental study on swelling characteristics of sand-bentonite mixture for nuclear waste disposal", Soils and Foundations, 39(2), pp. 83-97 (1999).

26. Lingnau, B.E., Graham, J., Yarechewski, D., et al. "Effects of temperature on strength and compressibility of sand-bentonite buffer", Engineering Geology, 41, pp. 103-115 (1996).

27. ENERSA. "Full-scale engineered barriers experiment for a deep geological repository for high-level radioactive waste in crystalline host rock (FEBEX project)", EUR 19147, Nuclear Science and Technology Series, Luxembourg (2000).

28. Mukherjee, K. and Mishra, A.K. "Evaluation of hydraulic and strength characteristics of sand-bentonite mixtures with added tire fiber for landfill application liner", Journal Environmental Engineering, 145(6) (2019). https://doi.org/10.1061/(ASCE) EE.1943-7870.0001537

29. ANDRA, Référentiel du site Meuse/Haute Marne, Report CRPADS040022_B. Chatenay-Malabry, 2, ANDRA (2005).

30. Knellwolf, C., Peron, H., and Laloui, L. "Geotechnical analysis of heat exchanger piles", Journal of Geotechnical and Geoenvironmental Engineering, 137(10), pp. 890-902 (2011).

31. Oclon, P., Taler, D., Cisek, P., et al. "FEM-based thermal analysis of underground power cables located in backfills made of different materials", Strength of Materials, 47(5), pp. 770-780 (2015).

32. Tanaka, N., Graham, J., and Crilly, T. "Stressstrain behavior of reconstituted illite clay at different temperature", Engineering Geology, 47, pp. 339-350 (1997).

33. Abuel-Naga, H.M., Bergado, D.T., Ramana, G.V., et al. "Experimental evaluation of engineering behavior of soft Bangkok clay under elevated temperature", Journal of Geotechnical and Geoenvironmental Engineering, 132(7), pp. 902-910 (2006).

34. Marques, M.E.S. "Strain-rate and temperature effect on consolidation of natural clays", MSc Thesis, Federal University of Rio de Janeiro, Brazil (1996).

35. Horpibulsuk, S. "Analysis and assessment of engineering behavior of cement stabilized clays", PhD Dissertation, Saga University, Japan (2001).

36. Rios, S. and Baudet, B.A. "On the shearing behaviour of an artificially cemented soil", Acta Geotechnica, 9, pp. 215-226 (2013).

37. Amini, Y., Hamidi, A., and Asghari, E. "Shear strength-dilation characteristics of cemented sandgravel mixtures", International Journal Geotechnical Engineering, 8(4), pp. 406-413 (2014). 
38. Mollamahmutoglu, M. and Avci, E. "Effect of cement grain size on the geotechnical properties of stabilized clay", Scientia Iranica, 26(6), pp. 3196-3206 (2019).

39. Bushra, I. and Robinson, R.G. "Shear strength behavior of cement treated marine clay", International Journal of Geotechnical Engineering, 6, pp. 455-465 (2012).

40. Hamidi, A., Tourchi, S., and Khazaei, C. "Thermomechanical constitutive model for saturated clays based on critical state theory", International Journal of Geomechanics, 15(1) (2015). https://doi. org/10.1061/(ASCE)GM.1943-5622.0000402

41. Hamidi, A. and Khazaei, C. "A thermo-mechanical constitutive model for saturated clays", International Journal of Geotechnical Engineering, 4(4), pp. 445-459 (2010).

42. Tourchi, S. and Hamidi, A. "Thermo-mechanical constitutive modeling of unsaturated clays based on the critical state concepts", Journal of Rock Mechanics and Geotechnical Engineering, 7(2), pp. 193-198 (2015).

43. Hamidi, A., Tourchi, S., and Kardooni, F. "A critical state based thermo-elasto-plastic constitutive model for structured clays", Journal of Rock Mechanics and Geotechnical Engineering, 9(6), pp. 1094-1103 (2017).

44. Hueckel, T. and Pellegrini, R. "Modeling of thermal failure of saturated clays", Int. Symp. on Numerical Models in Geomechanics-NUMOG III, Niagara Falls, Canada, pp. 81-90 (1989).

45. Hueckel, T., Francois, B., and Laloui, L. "Temperature-dependent internal friction of clay in a cylindrical heat source problem", Géotechnique, 61(10), pp. 831-844 (2011).

46. Burghignoli, A., Desideri, A., and Miliziano, S. "A laboratory study on the thermo mechanical behaviour of clayey soils", Canadian Geotechnical Journal, 37, pp. 764-780 (2000).

47. Cekerevac, C. "Thermal effects on the mechanical behaviour of saturated clays: an experimental and constitutive study", Doctoral Thesis No 2828, Ecole polytechnique Fédérale de Lausanne, Switzerland (2003).

48. Hueckel, T. and Baldi, G. "Thermoplasticity of saturated clays: Experimental constitutive study", Journal of Geotechnical Engineering, 116(12), pp. 17781796 (1990).

49. Graham, J., Tanaka, N., Crilly, T., and Alfaro, M. "Modified cam-clay modelling of temperature effects in clays", Canadian Geotechnical Journal, 38(3), pp. 608-621 (2001).
50. Wang, M.C., Benway, J.M., and Arayssi, A.M., The Effect of Heating on Engineering Properties of Clays, ASTM Special Technical Publication, pp. 139-158 (1990).

\section{Biographies}

Amir Hamidi is a Professor in Geotechnical Engineering at Kharazmi University, Iran. He received his BS, MSc, and PhD degrees in Civil Engineering from Sharif University of Technology in Tehran, Iran in 1997, 1999, and 2005, respectively. He was a visiting scholar at Barcelona Tech (UPC), Spain in 2018. His research interests include experimental soil mechanics and constitutive modeling, ground improvement (dynamic compaction and cemented soils), and environmental geotechnics (coupled thermal problems and contaminated soils). He has published five books, 80 more scientific articles, and about 100 presentations in conferences related to his research fields.

Atena Shirasb received her BS degree in Civil Engineering from Zanjan University, Iran. She continued graduate studies in Geotechnical Engineering in Sharif University of Technology in Tehran, Iran about liquefaction potential of silty sands and received her MSc degree in 2011. She graduated with a PhD degree in Geotechnical Engineering from Kharazmi University in 2020. Her PhD thesis was about the evaluation of thermal behavior of sand-bentonite mixtures under supervision of Professor Hamidi. At present, she is working as a project manager in geotechnical projects at Mandro Consulting Engineers Company. Her research interests are in the fields of experimental study of thermomechanical behavior of soils, thermal constitutive modeling, and liquefaction potential of soils.

Mohammad Mehdi Ahmadi received his BS and MSc degrees in Civil Engineering from Sharif University of Technology in Tehran, Iran in 1978 and 1988, respectively, and his $\mathrm{PhD}$ degree in Civil Engineering from the University of British Columbia, Canada in 2000. He is currently a Professor in Geotechnical Engineering at Sharif University of Technology. His research interests lie in static and dynamic soil-structure interaction, numerical modeling, in-situ testing of soils, unsaturated soil mechanics, and geotechnical earthquake engineering. He has published two books and over 60 articles in the geotechnical engineering field. 